\title{
Saccharomyces Rrm3p, a 5' to 3' DNA helicase that promotes replication fork progression through telomeric and subtelomeric DNA
}

\author{
Andreas S. Ivessa, ${ }^{1}$ Jin-Qiu Zhou, ${ }^{1,2}$ Vince P. Schulz, Ellen K. Monson, and Virginia A. Zakian ${ }^{3}$ \\ Department of Molecular Biology, Princeton University, Princeton, New Jersey 08544-1014, USA
}

In wild-type Saccharomyces cerevisiae, replication forks slowed during their passage through telomeric $\mathrm{C}_{1-3} \mathrm{~A} / \mathrm{TG}_{1-3}$ tracts. This slowing was greatly exacerbated in the absence of $R R M 3$, shown here to encode a $5^{\prime}$ to 3' DNA helicase. Rrm3p-dependent fork progression was seen at a modified Chromosome VII-L telomere, at the natural $\mathrm{X}$-bearing Chromosome III-L telomere, and at $\mathrm{Y}^{\prime}$-bearing telomeres. Loss of Rrm3p also resulted in replication fork pausing at specific sites in subtelomeric DNA, such as at inactive replication origins, and at internal tracts of $\mathrm{C}_{1_{-3}} \mathrm{~A} / \mathrm{TG}_{1_{-3}}$ DNA. The ATPase/helicase activity of Rrm3p was required for its role in telomeric and subtelomeric DNA replication. Because Rrm3p was telomere-associated in vivo, it likely has a direct role in telomere replication.

[Key Words: Telomere; helicase; telomerase; replication; RRM3; yeast]

Received February 7, 2002; revised version accepted April 10, 2002.

Telomeres are the natural ends of eukaryotic chromosomes. In most organisms, the very ends of chromosomes consist of simple repeated sequences. For example, Saccharomyces cerevisiae chromosomes end in $350 \pm 75$ bp of $\mathrm{C}_{1-3} \mathrm{~A} / \mathrm{TG}_{1-3}$ DNA. Middle repetitive DNA elements are often found immediately internal to the simple repeats. Saccharomyces has two types of subtelomeric repeats, the $\mathrm{Y}^{\prime}$ element, which is found in up to four tandem copies on about two-thirds of yeast telomeres, and the $\mathrm{X}$ element, which is found on virtually all telomeres (Chan and Tye 1983). The telomeric repeats are assembled into a non-nucleosomal DNA protein complex, the telosome (Wright et al. 1992), which contains multiple copies of the $\mathrm{C}_{1_{-3}} \mathrm{~A} / \mathrm{TG}_{1_{-3}}$-binding Rap1 protein (Conrad et al. 1990; Wright et al. 1992), as well as Sir proteins, Rif proteins, the single-strand $\mathrm{TG}_{1-3}$-DNAbinding Cdc13p (Bourns et al. 1998; Tsukamoto et al. 2001), and the heterodimeric Ku complex (Gravel et al. 1998). In contrast, $\mathrm{X}$ and $\mathrm{Y}^{\prime}$ DNA are assembled into nucleosomes (Wright et al. 1992). However, subtelomeric nucleosomes differ from nucleosomes in most other regions of the genome as they are also bound by the Sir (Hecht et al. 1996; Strahl-Bolsinger et al. 1997) and Ku (Martin et al. 1999) complexes.

\footnotetext{
${ }^{1}$ These authors contributed equally to this work.

${ }^{2}$ Present address: Shanghai Institute of Biochemistry and Cell Biology, Chinese Academy of Sciences, Shanghai 200031, P.R. China. ${ }^{3}$ Corresponding author.

E-MAIL vzakian@molbio.princeton.edu; FAX (609) 258-1701.

Article and publication are at http://www.genesdev.org/cgi/doi/10.1101/ gad.982902.
}

Because conventional DNA polymerases cannot replicate the very ends of linear DNA molecules, special mechanisms are required to prevent the loss of terminal DNA. In most eukaryotes, including Saccharomyces, this end-replication problem is solved by telomerase, a reverse transcriptase that uses its RNA component as a template to lengthen the G-rich strand of telomeric DNA. However, in the absence of telomerase, only a few base pairs of telomeric DNA are lost per telomere per S phase (Lundblad and Szostak 1989). Thus, most of the $\mathrm{C}_{1-3} \mathrm{~A} / \mathrm{TG}_{1-3}$ telomeric tract and the entire subtelomeric DNA are duplicated by conventional, semiconservative DNA replication. In Saccharomyces, semiconservative replication of both the subtelomeric repeats (McCarroll and Fangman 1988; Ferguson et al. 1991) and the telomeric $\mathrm{C}_{1-3} \mathrm{~A} / \mathrm{TG}_{1-3}$ tracts (Wellinger et al. 1993a) as well as telomerase elongation of telomeres (Marcand et al. 2000) occur late in the $S$ phase.

The Saccharomyces Pif1p, a 5' to 3' DNA helicase (Lahaye et al. 1993), is a negative regulator of the telomerase pathway (Schulz and Zakian 1994; Zhou et al. 2000). Telomere length is inversely proportional to the amount of Pif1p: Overexpression of Pif1p causes telomere shortening, and reduced expression results in lengthening. Both effects on telomere length require the helicase activity of Pif1p (Zhou et al. 2000). In the absence of Pif1p, telomerase-mediated de novo telomere addition at spontaneous and induced chromosome breaks is elevated 200- to 1000-fold (Schulz and Zakian 1994; Mangahas et al. 2001; Myung et al. 2001). 
The PIF1 gene is the prototype member of a helicase subfamily that is conserved from yeast to humans (for review, see Bessler et al. 2001). Although Saccharomyces has 134 ORFs that encode helicase-like proteins (Shiratori et al. 1999), only one of these, Rrm3p, has significant similarity to Piflp by the criterion of a BLAST search (Zhou et al. 2000). RRM3 encodes a 723-amino-acid protein that is $60 \%$ similar to Piflp over a 485 -amino-acid region that encompasses the seven helicase motifs (Bessler et al. 2001). RRM3 was first identified because its mutation increases recombination in ribosomal DNA (rDNA; Keil and McWilliams 1993), which results in the accumulation of rDNA circles (Ivessa et al. 2000). However, this recombination is probably a secondary consequence of defects in rDNA replication as, in the absence of Rrm3p, replication forks pause at multiple sites throughout the rDNA. Separation of converged replication forks within the rDNA is especially impaired in rrm $3 \Delta$ cells. Pif1p also influences rDNA replication, although its effects are relatively modest.

In this paper, we describe the role of Rrm3p at telomeres. Although Rrm3p, like Pif1p, is a $5^{\prime}$ to $3^{\prime}$ DNA helicase, we found that Rrm3p was important for conventional replication of telomeric DNA, rather than for the telomerase pathway. In the absence of Rrm3p, a natural pausing of replication forks within telomeric $\mathrm{C}_{1-3} \mathrm{~A} / \mathrm{TG}_{1-3}$ repeats was greatly increased, and replication forks paused at specific sites within subtelomeric DNA. The ATPase/helicase function of Rrm3p was needed for its role at telomeres. Because Rrm3p was telomere-associated, its effects on telomere replication are likely direct.

\section{Results}

\section{Rrm3p is an ATPase and 5' to 3' DNA helicase}

We were unable to purify full-length Rrm3p from baculovirus-infected Sf9 cells, bacteria, or yeast, encountering problems similar to those reported for the full-length Saccharomyces Sgslp helicase (Bennett et al. 1998). Therefore, we expressed a truncated version of Rrm3p as a GST fusion protein in $S$. cerevisiae. This polypeptide, hereafter called Rrm $3 \mathrm{p} \Delta \mathrm{N}$, contained amino acids 194 to 723 of the 723 -amino-acid protein, including all seven helicase motifs as well as 56 amino acids amino-terminal of the first helicase motif (Bessler et al. 2001). $\operatorname{Rrm} 3 \mathrm{p} \Delta \mathrm{N}$ was expressed under the control of a galactose-inducible promoter. Only galactose-grown cells contained a polypeptide of the appropriate molecular weight that cross-reacted with anti-Rrm $3 p$ antibodies (Fig. 1B, cf. lanes 2 and 3). Rrm $3 p \Delta N$ was purified to near homogeneity (Fig. 1A and B show, respectively, Coomassie blue-stained or immunoblotting of $\operatorname{Rrm} 3 \mathrm{p} \Delta \mathrm{N}$ throughout its purification).

The purified $\operatorname{Rrm} 3 \mathrm{p} \Delta \mathrm{N}$ had $\mathrm{Mg}^{2+}$-dependent, singlestranded DNA stimulated ATPase activity (Fig. 1C). To determine if Rrm3p $\Delta \mathrm{N}$ had helicase activity, we used a partially duplex DNA substrate in which a 36-mer oligonucleotide and a 25-mer oligonucleotide were an- nealed at, respectively, the $5^{\prime}$ and $3^{\prime}$ ends of linear, single-stranded M13 DNA (Fig. 1D). DNA helicases will load onto the single-stranded region between the two oligonucleotides. A $5^{\prime}$ to $3^{\prime}$ DNA helicase will move $5^{\prime}$ to $3^{\prime}$ on the single-stranded segment and displace the 36-mer oligonucleotide, whereas a $3^{\prime}$ to $5^{\prime}$ DNA helicase will move $3^{\prime}$ to $5^{\prime}$ and displace the 25 -mer oligonucleotide. Because Rrm3p $\Delta$ N (Fig. 1D, lane 5), like Pif1p (Fig. 1D, lane 6), displaced only the 36-mer oligonucleotide, we conclude that $\operatorname{Rrm} 3 \mathrm{p} \Delta \mathrm{N}$ is a $5^{\prime}$ to $3^{\prime}$ DNA helicase. This helicase activity was ATP-dependent (Fig. 1D, lane 3) and $\mathrm{Mg}^{2+}$-dependent (Fig. 1D, lane 4).

Rrm3p affects telomere length and the ability of Pif1p to inhibit de novo telomere addition

Previous work showed that loss of Pif1p increases telomere length and de novo telomere addition (Schulz and Zakian 1994). Therefore, we examined telomere length and de novo telomere addition in rrm3 $\Delta$ cells. DNA from wild-type and mutant cells was digested with $\mathrm{XhOI}$ and examined by Southern hybridization using a $\mathrm{C}_{1-3} \mathrm{~A} /$ $\mathrm{TG}_{1-3}$ telomeric probe. Loss of Pif1p resulted in an $\sim 160$ bp increase in telomere length (Fig. 2A). Deletion of $R R M 3$ resulted in a more modest $(\sim 75-\mathrm{bp})$ lengthening. If Rrm3p, like Pif1p, inhibits telomerase, telomeres would be even longer in a pif1 $r r m 3 \Delta$ strain than in either singly mutant strain. Alternatively, if Piflp is a more effective telomerase inhibitor than Rrm3p, telomeres might be the same length in the doubly mutant strain as they are in a pif1 $\Delta$ strain. In contrast to both expectations, telomeres in pif1 $\Delta$ rm $3 \Delta$ cells were similar in length to $\operatorname{rrm} 3 \Delta$ telomeres (Fig. 2A).

To determine rates of telomere addition, we used a yeast artificial chromosome (YAC) that had LEU2 on one arm, URA3 near the telomere of the other arm, and a tract of Oxytricha $\mathrm{C}_{4} \mathrm{~A}_{4} / \mathrm{T}_{4} \mathrm{G}_{4}$ telomeric DNA internal to the URA3 gene (Fig. 2B; Schulz and Zakian 1994). The Oxytricha sequence is used as a substrate for telomere addition in yeast (Pluta et al. 1984). Cells that express Ura3p die on medium containing 5-fluoroorotic acid (FOA). If de novo telomere addition occurs within the right arm of the YAC, the distal portion of its right arm, including the URA3 gene, will be lost, generating a $\mathrm{Leu}^{+}$ FOA-resistant $\left(\mathrm{FOA}^{\mathrm{R}}\right)$ colony. Consistent with previous results (Schulz and Zakian 1994), wild-type cells had a low rate of de novo telomere addition $\left(10^{-6}\right)$, and most addition events (16/18) occurred within the $\mathrm{C}_{4} \mathrm{~A}_{4} / \mathrm{T}_{4} \mathrm{G}_{4}$ tract (Fig. 2B), whereas telomere addition was increased 240 -fold in the pif1 $\Delta$ strain, and most $(17 / 18)$ of these events did not occur at the $\mathrm{C}_{4} \mathrm{~A}_{4} / \mathrm{T}_{4} \mathrm{G}_{4}$ tract (Fig. 2B). The rrm $3 \Delta$ strain had the same rate of de novo telomere addition as wild type $\left(10^{-6}\right)$, and most of these events $(15 / 16)$ occurred at the $\mathrm{C}_{4} \mathrm{~A}_{4} / \mathrm{T}_{4} \mathrm{G}_{4}$ tract. The rate of de novo telomere addition in the pif1 $\operatorname{rrm} 3 \Delta$ strain was 28 -fold higher than in wild type. Thus, deletion of $R R M 3$ alone did not affect de novo telomere addition, and its deletion in a pif1s strain partially suppressed the elevated telomere addition phenotype of pif1s cells (Fig. 2B). Taken together, the telomere length and telomere 

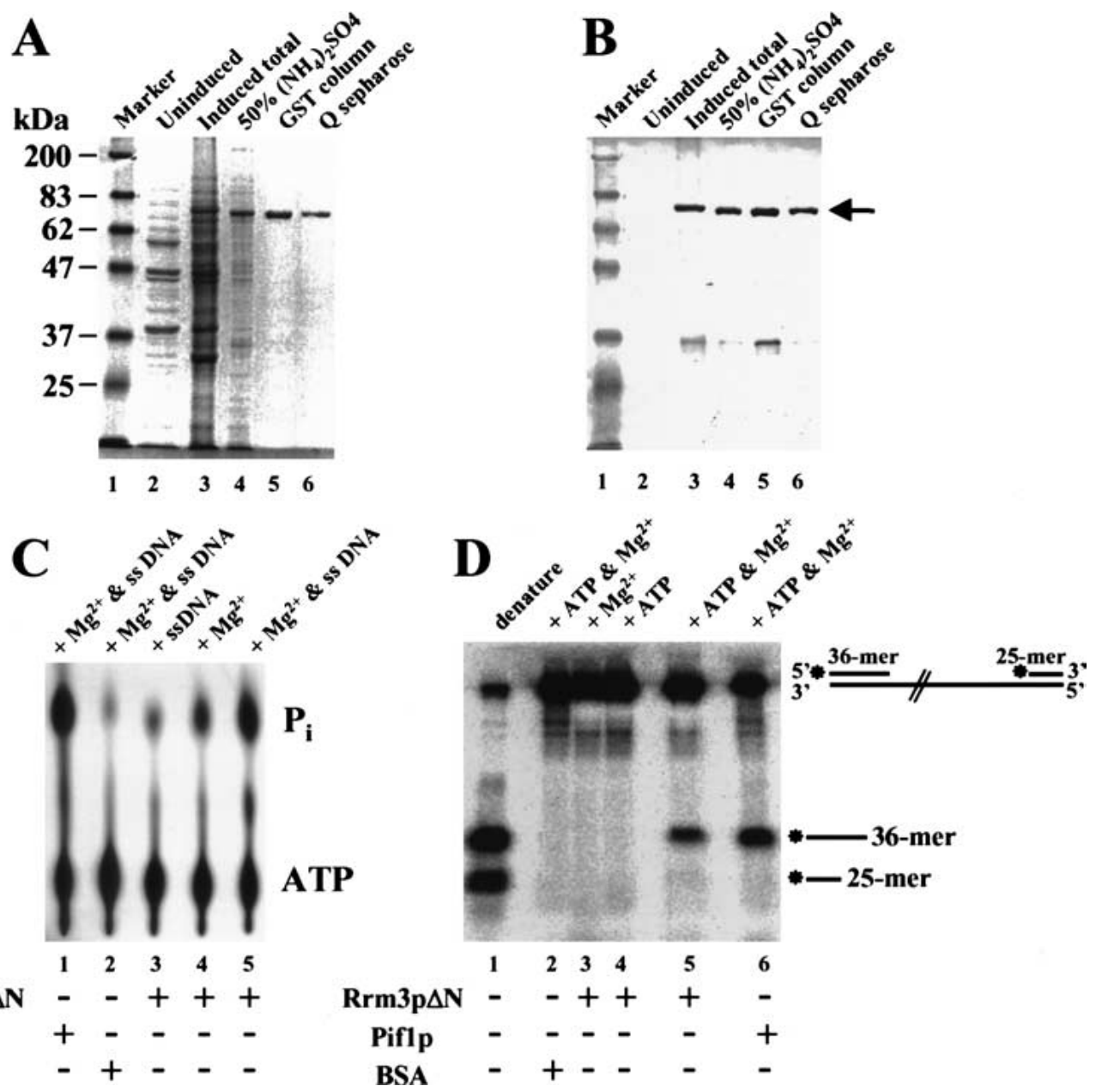

Figure 1. Recombinant Rrm3 protein has ATPase and 5' to $3^{\prime}$ DNA helicase activity. A truncated form of Rrm3p (Rrm3p $\left.\Delta N\right)$ was fused to GST and expressed in Saccharomyces cerevisiae under control of the galactose-inducible GAL1 promoter. Yeast proteins were resolved by $8 \%$ SDS-PAGE and detected by $(A)$ Coomassie blue staining or $(B)$ immunoblotting. In $A$ and $B$, lane 1 is size markers in kilodaltons. (Because covalent coupling of marker proteins to the blue dye used for visualization affects their mobility in SDS-PAGE, the $83-\mathrm{kD}$ marker protein has a slower mobility than the $87-\mathrm{kD}$ Rrm3p $\Delta$ N.) Lanes 2 and 3 contain a crude extract of proteins from glucose grown (lane 2) or galactose grown (lane 3) cells. Lanes 4-6 contain proteins from galactose-grown cells after sequential purification by $50 \%$ ammonium sulfate precipitation (lane 4), fractionation on Glutathione sepharose 4B (lane 5), and fractionation on Q-sepharose (lane 6). (C) The ATPase reaction products were developed in a polyethylimine (PEI) cellulose plate and visualized on a Molecular Dynamics PhosphorImager. Lane 5 contains $\left[\gamma-\mathrm{P}^{32}\right] \mathrm{ATP}, \mathrm{M} 13$ single-stranded DNA, $\mathrm{Mg}^{2+}$, and Rrm3p $\Delta \mathrm{N}$. The other lanes were the same except lane 1 had Piflp in place of Rrm3p $\Delta \mathrm{N}$; lane 2 had BSA in place of Rrm3p $\Delta \mathrm{N}$; lane 3 had no $\mathrm{Mg}^{2+}$; and lane 4 had no single-stranded DNA. $(D)$ For the helicase assay, the DNA substrate was linear M13 single-stranded DNA to which kinase labeled 36-mer and 25-mer oligonucleotides had been annealed. Lane 1 contains the heat-denatured DNA substrate; lane 5 contains Rrm3p $\Delta \mathrm{N}$, the DNA substrate, ATP and $\mathrm{Mg}^{2+}$. The other lanes are the same as lane 5 except lane 2 contains BSA in place of Rrm3p $\Delta \mathrm{N} ;$ lane 3 has no ATP; lane 4 has no $\mathrm{Mg}^{2+}$; and lane 6 contains Piflp in place of Rrm3p $\Delta \mathrm{N}$.

addition data indicate that although Rrm3p affects telomeres, it acts otherwise than Piflp.

Replication forks slow as they move through the Chromosome VII-L telomere, and this slowing is exacerbated in the absence of Rrm3p

To determine if Rrm3p affects conventional replication of telomeres, we used two-dimensional (2D) gel electrophoresis (Brewer and Fangman 1987). To examine replication of the left telomere of Chromosome VII, we in- serted URA3 within the ADH4 gene, the most distal gene on Chromosome VII-L, in such a way that it deleted the subtelomeric repeats (Fig. 3A). Replication of the end of Chromosome VII-L occurs from an origin of replication $(A R S)$ that lies internal to the terminal ClaI fragment (Fig. 3A), such that the VII-L terminal restriction fragment is replicated by leftward-moving forks. In 2D gels, forked replication intermediates emanate from the position of nonreplicating restriction fragments (Fig. 3A, labeled $1 \mathrm{~N}$ ), become increasingly nonlinear until the replication fork reaches the middle of the fragment, and 

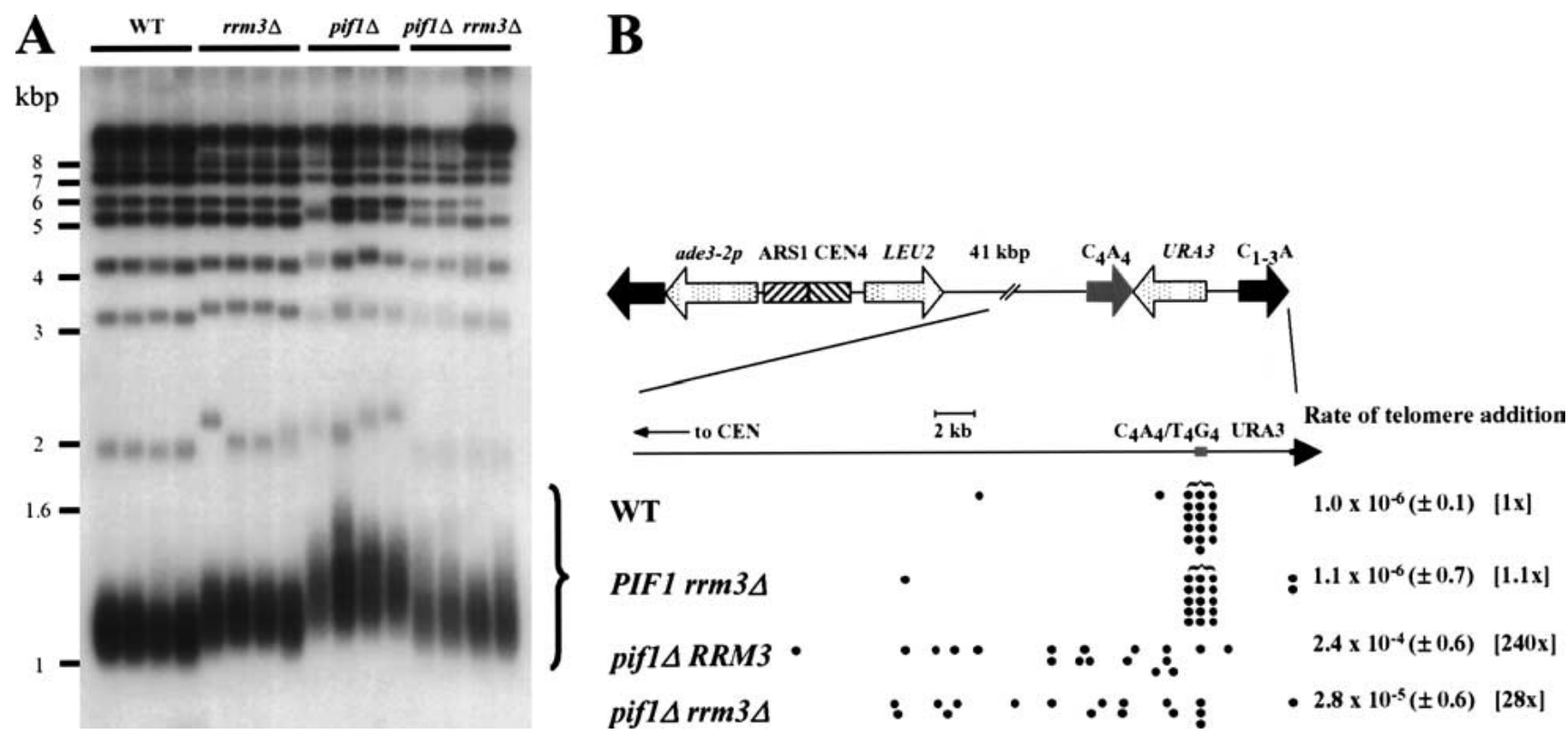

Figure 2. Rrm $3 p$ affects telomere length and de novo telomere addition but not in the same ways as Piflp. (A) DNA was prepared from

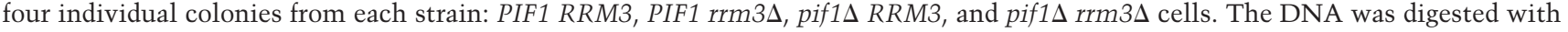
XhoI, separated by electrophoresis in a $0.7 \%$ agarose gel, prepared for Southern analysis, and probed with a $\mathrm{C}_{1-3} \mathrm{~A} / \mathrm{TG}_{1-3}$ telomeric probe. The large curly brace indicates the terminal XhoI fragments from $\mathrm{Y}^{\prime}$-bearing telomeres. Molecular weight markers are in kilobase pairs. $(B)$ The rate of de novo telomere formation on a YAC was determined using 10 plate fluctuation tests (Lea and Coulson 1949), conducted 2-4 times per strain, as described in Schulz and Zakian (1994). Because Leu ${ }^{+}$FOA $^{\mathrm{R}}$ cells can also be generated by point mutations in $U R A 3$, the sites of telomere addition in multiple independent $\mathrm{Leu}^{+} \mathrm{FOA}^{\mathrm{R}}$ clones were mapped to determine the fraction of these events that were due to de novo telomere addition. Each filled circle marks the physical end of a YAC in one such colony. Leu ${ }^{+}$ FOA $^{\mathrm{R}}$ colonies that contained a YAC of unaltered length were presumed to arise from point mutations in URA3. Numbers in parentheses indicate the range of values seen in independent experiments. Numbers in brackets are the fold difference relative to the wild-type strain.

then become increasingly more linear until they reenter the arc of simple linear molecules with a mass of $2 \mathrm{~N}$ (Brewer and Fangman 1987).

When DNA from asynchronous wild-type cells was digested with ClaI and examined by 2D gels, an arc of forked replication intermediates was detected (Fig. 3B). The pattern for rrm $3 \Delta$ cells was similar except that there was intense hybridization at the $2 \mathrm{~N}$ position on the arc of linear DNA molecules (hereafter called the $2 \mathrm{~N}$ spot; Fig. 3B, arrow). Although the $2 \mathrm{~N}$ spot was also evident in wild-type DNA, it was more intense in $\operatorname{rrm} 3 \Delta \mathrm{DNA}$. To estimate the amount of telomeric DNA in the $2 \mathrm{~N}$ spot, we measured the signal in both the $2 \mathrm{~N}$ spot and in unreplicated DNA (1N spot) and determined the $2 \mathrm{~N} / 1 \mathrm{~N}$ ratio. This ratio was $10.1 \pm 2.7$-fold higher in $\operatorname{rrm} 3 \Delta$ DNA than in wild-type DNA (average \pm standard error; based on five independent experiments).

Because $2 \mathrm{~N}$ spot DNA has a mass of nearly $2 \mathrm{~N}$ and a nearly linear structure, it behaves as if the Chromosome VII sister chromatids are almost fully replicated (see cartoon in Fig. 3A). Given that the telomere comprises $<10 \%$ of the ClaI restriction fragment (Fig. 3A), this behavior suggests that the sister chromatids were held together within the telomere itself. The modified VII-L telomere has a BamHI site 6 bp away from the start of the $\mathrm{C}_{1-3} \mathrm{~A} / \mathrm{TG}_{1-3}$ telomeric tract. To determine if $2 \mathrm{~N}$ spot DNA is held together within the telomere, the same
DNA preparations that had been examined after ClaI digestion were instead digested with BamHI (Fig. 3B). Because the $2 \mathrm{~N}$ spot was nearly gone after BamHI digestion (Fig. 3B, right panels), it was caused largely by sister chromatids held together within the $\mathrm{C}_{1-3} \mathrm{~A} / \mathrm{TG}_{1-3}$ tract.

\section{The catalytic activity of Rrm3p is needed for telomere replication}

DNA helicases can be multifunctional, having activities in addition to the unwinding of duplex DNA (see, e.g., Sung et al. 1988; Formosa and Nittis 1999). To determine if the ATPase/helicase activity of Rrm3p is needed for replication of telomeric DNA, we used an RRM3 allele in which the invariant lysine in the ATP-binding pocket was mutated to alanine (K260A; Ivessa et al. 2000). Converting this invariant lysine to an alanine eliminates the helicase activity of all helicases that have been thus modified, including Piflp (Zhou et al. 2000). A centromere plasmid bearing either the K260A rrm3 or wildtype $R R M 3$ genes was introduced into $\operatorname{rrm} 3 \Delta$ and wildtype strains. Western analysis showed that the K260A mutant allele produces close to wild-type levels of Rrm3p (Ivessa et al. 2000). DNA from each strain was digested with ClaI, and analyzed by 2D gels (Fig. 3C). The plasmid-borne $R R M 3$ suppressed the telomere rep- 
A

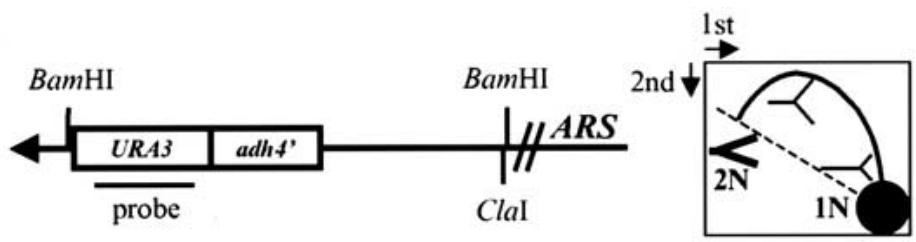

B

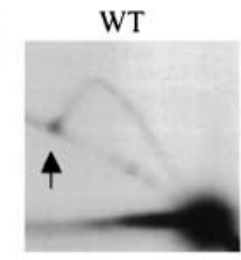

ClaI
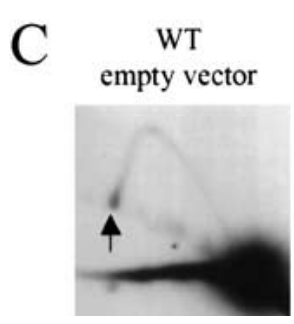

$r m 3 \Delta$

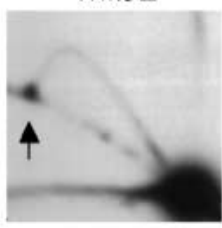

ClaI

rrm $3 \Delta$ vector-RRM3
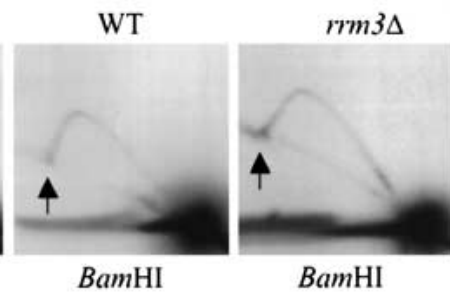

$r m 3 \Delta$ empty vector

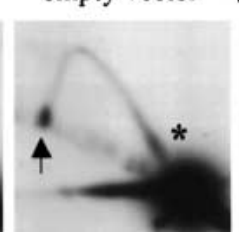

mm3 vector-rrm3-K260A

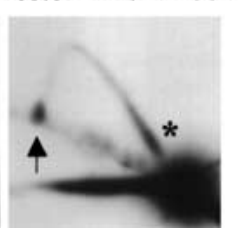

Figure 3. Replication of telomere VII-L is impaired in the absence of Rrm3p. (A) Structure of the left telomere of Chromosome VII after insertion of URA3 in a strain in which URA3 was deleted from its normal location. The $U R A 3$ probe indicated in $A$ was used in $B$ and $C$ as well as in Figure 4. Digestion with ClaI generates a 3.8 -kb fragment containing the VII-L telomere. $A$ has a cartoon of the expected pattern of replication intermediates for simple forks moving leftward toward the telomere after their separation in 2D gels. The arc of linear molecules is denoted by the dotted line, $1 \mathrm{~N}$ marks the position of an unreplicated restriction fragment, and $2 \mathrm{~N}$ is the same molecule immediately before its replication is complete. The $2 \mathrm{~N}$ intermediate is drawn in thick lines to emphasize that it was more abundant than other forked replication intermediates. (B) DNA from wild-type (WT) or rrm3 $3 \Delta$ cultures was digested with either ClaI (left two panels) or BamHI (right two panels). The arrows in this and subsequent gels denote the position of the $2 \mathrm{~N}$ spot. (C) DNA was prepared from cultures of wild-type or $\operatorname{rrm} 3 \Delta$ strains carrying the plasmid YCplac111, YCplac111 containing RRM3, or YCplac111 containing the rrm3 K260A allele. DNA was digested with ClaI and analyzed by $2 \mathrm{D}$ gels. Asterisks mark the region downstream of $A D H 4$ where replication forks slow in the absence of Rrm3p.

lication defects of the rrm3s strain (Fig. 3C, second panel), showing that these defects were owing to the absence of Rrm3p. Telomere replication was equally impaired in the strain expressing the K260A Rrm3p (Fig. 3C, fourth panel) as in the strain lacking Rrm3p (Fig. 3C, third panel). Thus, the ATPase/helicase activity of Rrm3p is needed for telomere replication.

In addition to the $2 \mathrm{~N}$ spot, DNA from $\mathrm{rrm} 3 \Delta$ cells showed increased hybridization near the proximal end of the 3.8-kb ClaI fragment (Fig. 3C, asterisk). This pause, which was not detected in DNA from wild-type cells, mapped to a position downstream of $A D H 4$.

\section{The appearance of the $2 \mathrm{~N}$ spot is cell cycle regulated}

If the $2 \mathrm{~N}$ spot is an intermediate in telomere replication, it should be absent in DNA from $G_{1}$ cells and enriched during replication of telomeric DNA, which occurs in the second half of the S phase (McCarroll and Fangman 1988; Wellinger et al. 1993a). To test these predictions, cultures were arrested in late $G_{1}$ phase by incubation with $\alpha$ factor. After arrest, cells were removed from $\alpha$ factor (zero time point) and allowed to progress through the cell cycle. Samples were harvested at 15 -min intervals for analysis by fluorescent activated cell sorting (FACs; Fig. 4A) and by conventional (Fig. 4B) and 2D (Fig. 4D) gel electrophoresis. The $\alpha$-factor arrest and subsequent release were done at $22^{\circ} \mathrm{C}$ because a slower growth rate makes it easier to detect replication intermediates. At $22^{\circ} \mathrm{C}$, the rrm $3 \Delta$ strain grew somewhat slower (120min doubling time) than otherwise isogenic wild-type cells (105-min doubling time).
By the criterion of FACs analysis, the wild-type and $\operatorname{rrm} 3 \Delta$ strains proceeded similarly through $\mathrm{S}$ phase (Fig. 4A). At 30 min after $\alpha$-factor release, the majority of the cells in both strains were in $\mathrm{S}$ phase. In both strains, $\sim 80 \%$ and $\sim 90 \%$ of the cells had a $2 \mathrm{C}$ DNA content at, respectively, 60 and 75 min after $\alpha$ factor release. The major difference in the FACs profiles of the two strains was that at $105 \mathrm{~min}, 24 \%$ of the wild-type cells had a 1C DNA content, indicating movement into the $G_{1}$ phase of the next cell cycle, whereas at $105 \mathrm{~min}$, there were very few $1 \mathrm{C}$ cells in the rrm3 3 culture, suggesting that $r r m 3 \Delta$ cells took longer to traverse from late $S$ phase into the next cell cycle.

DNA from each time point was digested with ClaI and examined by conventional agarose gel electrophoresis (Fig. 4B). The $2 \mathrm{~N}$ spot generates a 7.6-kb ClaI fragment. The fraction of telomeric DNA in the $2 \mathrm{~N}$ spot as a function of position within the cell cycle is quantitated in Figure 4C. In both strains, the $2 \mathrm{~N}$ spot was transitory (Fig. 4B-D). In three independent synchrony experiments, the $2 \mathrm{~N}$ spot was only detected in the $45-\mathrm{min}$ sample in wild-type DNA. In rrm $3 \Delta$ cells, the $2 \mathrm{~N}$ spot peaked in the 60 -min sample but was also detected in the 45- and 75-min samples. Although FACs analysis indicated that the progress of chromosomal DNA replication was similar in the two strains (Fig. $4 \mathrm{~A}$ ), the $2 \mathrm{~N}$ spot peaked later and persisted for a longer period of time in rrm3s cells (Fig. 4C). DNA from each time point was also examined by 2D gels (Fig. 4D; data not shown). The $2 \mathrm{~N}$ spot and forked replication intermediates were only present in time points that contained the $7.6-\mathrm{kb}$ ClaI fragment. 
A
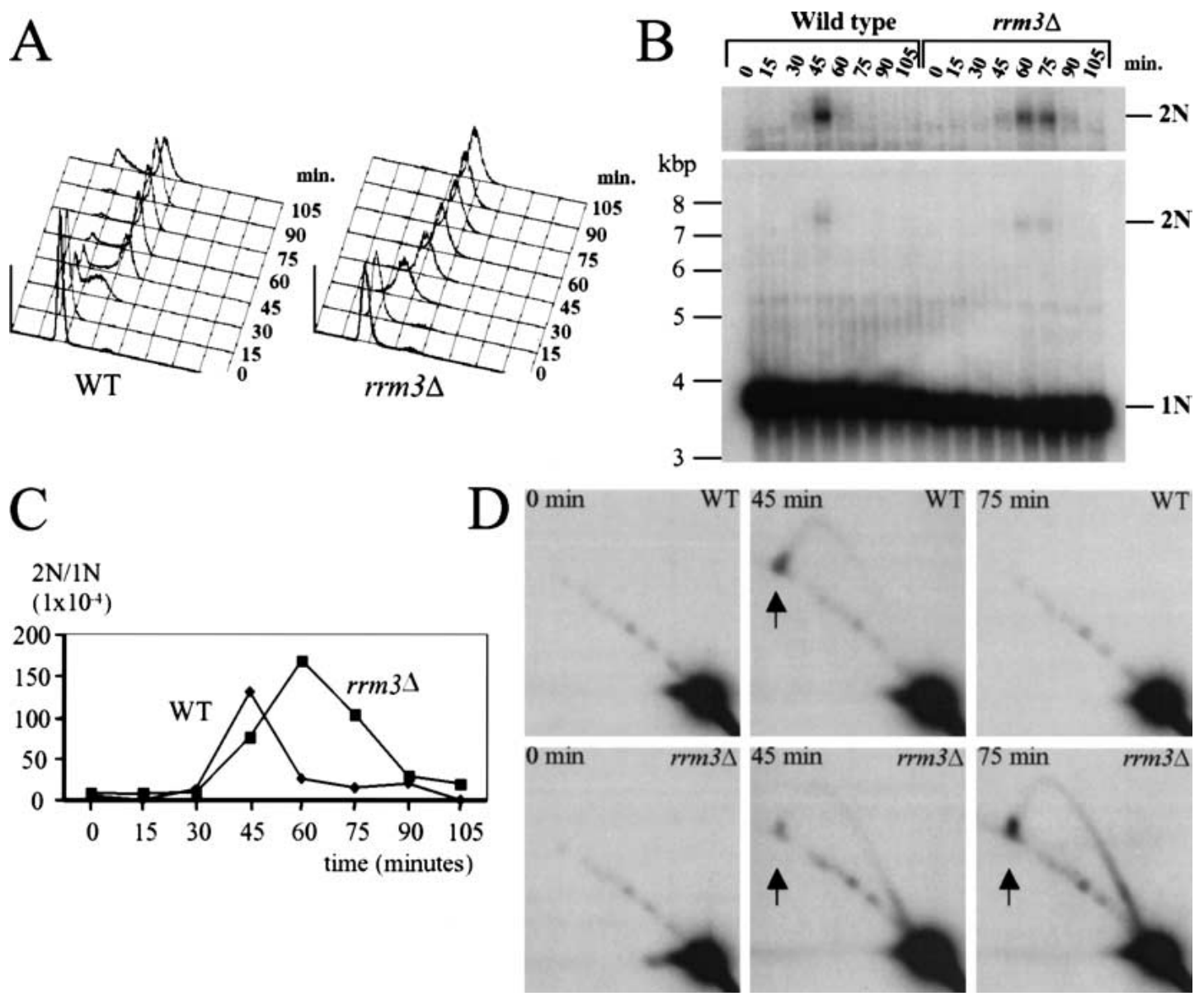

Figure 4. The $2 \mathrm{~N}$ spot is cell cycle regulated, appearing at the time of telomere replication. Wild-type or rrm $3 \Delta$ cells were $\mathrm{G}_{1}$ arrested with $\alpha$ factor and then removed from the $\alpha$ factor and allowed to progress through the cell cycle. Samples were prepared at the time of removal from $\alpha$ factor $(0 \mathrm{~min})$ and then at 15 -min intervals. $(A)$ Cells from each time point were analyzed by fluorescent activated cell sorting (FACs). (B) DNA samples from each time point were digested with ClaI, separated by conventional agarose gel electrophoresis, and hybridized with the URA3 probe (Fig. 3A). In a conventional gel, $2 \mathrm{~N}$-spot DNA migrates as a 7.6-kb linear fragment. The top panel shows a longer exposure of the $2 \mathrm{~N}$ spot region of the gel. $(C)$ The data in panel $B$ were quantitated; the $2 \mathrm{~N}$ to $1 \mathrm{~N}$ ratio is shown for each time point. (D) Each ClaI-digested DNA sample was also analyzed by 2D gel analysis; representative time points from both strains are shown.

Rrm3p is needed for timely replication of the telomere and subtelomeric DNA on Chromosome III-L

To determine if Rrm3p plays a role at natural telomeres, we used 2D gels to examine replication of the left telomere of Chromosome III in SphI-digested DNA from asynchronous cells (Fig. 5A). The left telomere of Chromosome III has $\mathrm{X}$ but no $\mathrm{Y}^{\prime}$ DNA (Button and Astell 1986). Although the $\mathrm{X}$ has an $A R S$, the ARS is inactive in wild-type cells (Newlon et al. 1993), such that replication of the terminal SphI fragment occurs by leftwardmoving forks (ARS is marked with an asterisk in Fig. $5 \mathrm{~A})$. The $2 \mathrm{D}$ gels revealed the expected arc of forked replication intermediates in both wild-type (Fig. 5A, left panel) and rrm3 DNA (Fig. 5A, center and right panels). Although the $2 \mathrm{~N}$ spot was visible in DNA from both strains (Fig. 5A, filled arrows), the $2 \mathrm{~N} / 1 \mathrm{~N}$ ratio was $9.4 \pm 3.7$-fold higher in $\operatorname{rrm} 3 \Delta$ than in wild-type DNA laverage \pm standard error; four independent experi- ments). There was also intense hybridization on the arc of forked intermediates at the position of the inactive ARS (Fig. 5A, asterisk). Again, replication pausing at this $A R S$ was seen in both wild-type and mutant cells but was $9.9 \pm 5.5$-fold more intense in rrm $3 \Delta$ cells (value is ratio of signal in pause divided by $1 \mathrm{~N}$ spot for $\operatorname{rrm} 3 \Delta$ divided by wild type ratio; average \pm standard error; four independent experiments). Intense hybridization was also detected at the position of $\sim 6$-kb linear fragments (Fig. 5A, marked by diamond). This structure was present in both mutant and wild-type DNA but was more abundant in $r r m 3 \Delta$ DNA. Because this spot was not present in DNA from $\mathrm{G}_{1}$-arrested cells (data not shown), it was not caused by cross-hybridization to a restriction fragment from another locus. If replication forks that are paused at the ARS break immediately ahead of the fork, they would generate an almost linear fragment of $6 \mathrm{~kb}$ (Fig. 5A, open arrowhead indicates the point of breakage). Because the replication intermediates for telomere III-L 
A

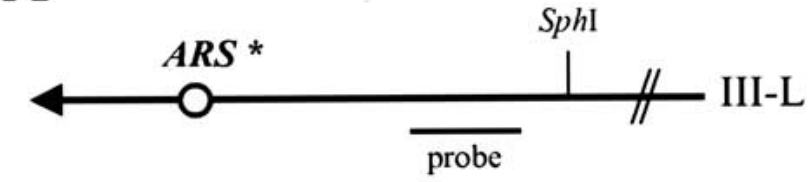

WT

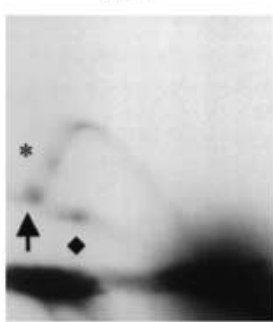

$\operatorname{rrm} 3 \Delta$
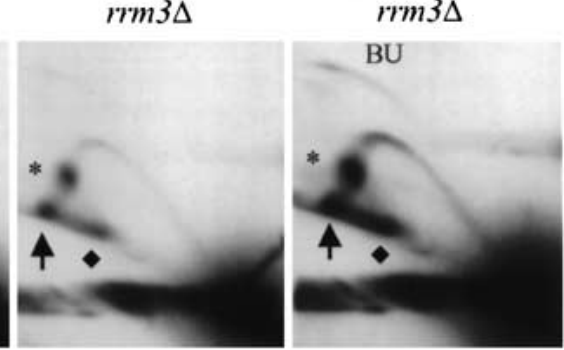

vector-rrm3-K260A

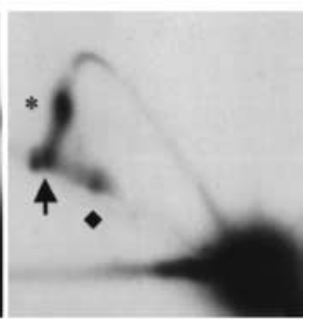

B
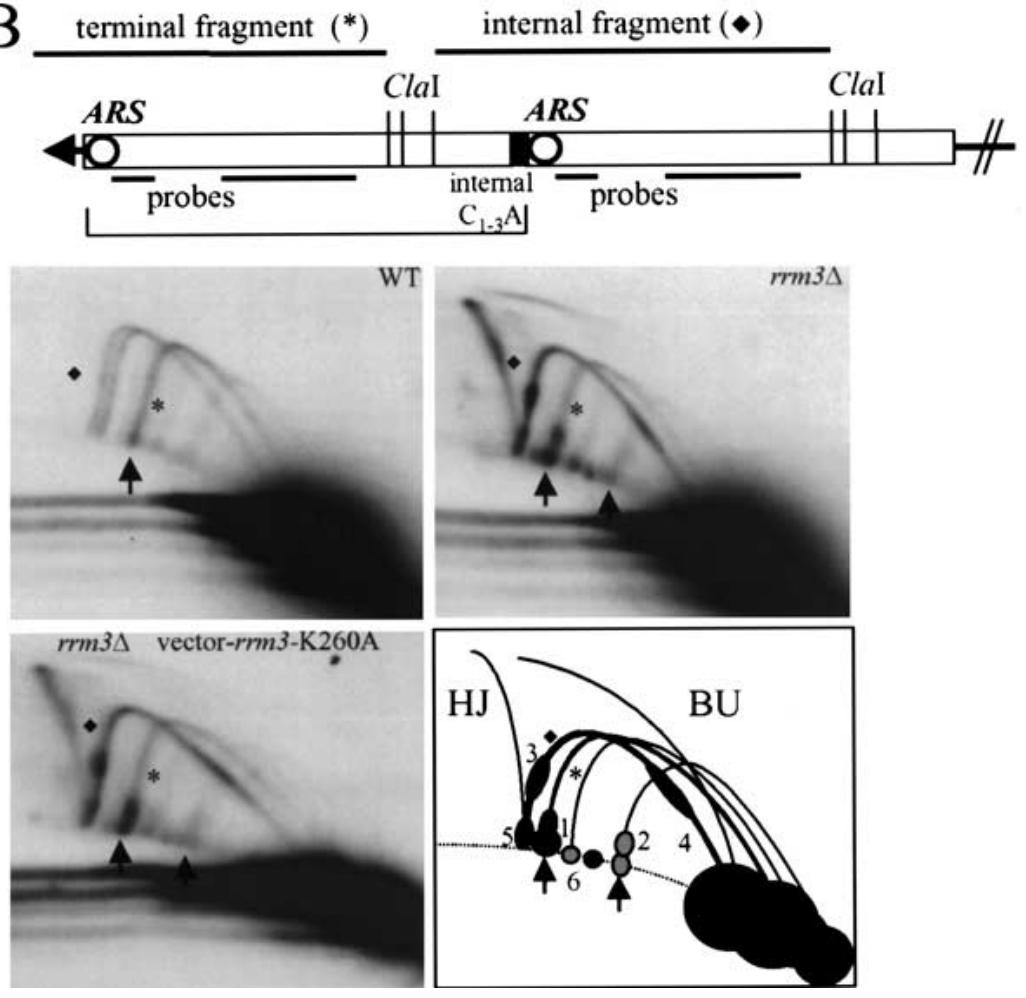

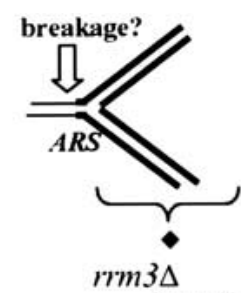

Figure 5. Rrm $3 p$ affects replication of natural, $\mathrm{X}$-, and $\mathrm{Y}^{\prime}$-bearing telomeres. $(A)$ Structure of the left telomere of Chromosome III. An inactive ARS in the subtelomeric $\mathrm{X}$ element, $1 \mathrm{~kb}$ from the chromosome end, is indicated by an asterisk. Genomic DNA was digested with SphI, which generates a 4-kb terminal fragment from Chromosome III-L, and analyzed by $2 \mathrm{D}$ gels using the probe shown in $A$. Pausing at the inactive $A R S$ is denoted by an asterisk. A diamond marks a molecule on the arc of simple linears that has a mass of $\sim 6 \mathrm{~kb}$. A $6-\mathrm{kb}$, almost linear fragment is generated by breakage in front of the fork stalled at the ARS (see cartoon). The third panel is a longer exposure of the second panel that makes it easier to see replication bubbles (BU). The fourth panel is the pattern in an rrm3 3 strain that carries the rrm3-K260A allele on plasmid YCplac111 (as in Fig. 3C). (B) Structure of $Y^{\prime}$ elements. $\mathrm{Up}$ to four tandem $\mathrm{Y}^{\prime}$ elements are found at a given telomere: the bracket indicates the position of the most terminal $\mathrm{Y}^{\prime}$ element on a hypothetical telomere containing two $\mathrm{Y}^{\prime}$ repeats. Genomic DNA from asynchronous cells was digested with ClaI and analyzed by 2D gels using the combination of probes shown in the cartoon. The pattern of replication intermediates for three strains is shown: RRM3 (WT), rrm3s, and rrm3s carrying the rrm3K260A allele on plasmid YCplac111. The arc labeled with an asterisk is the $5.3-\mathrm{kb}$ ClaI fragment from terminal $\mathrm{Y}^{\prime}$ long elements; the arc labeled with a diamond is the $6.2-\mathrm{kb} C l a \mathrm{I}$ fragment from internal $\mathrm{Y}^{\prime}$ long elements (two size variants of this fragment are visible in wild-type DNA). The rightmost arrow in the $r r m 3 \Delta$ gel is at the position for the $2 \mathrm{~N}$ spot for $\mathrm{Y}^{\prime}$ short telomeres. In the schematic of the $2 \mathrm{D}$ gel for $\operatorname{rrm} 3 \Delta \mathrm{Y}^{\prime} \mathrm{DNA}$, arrows point to the $2 \mathrm{~N}$ spot for $\mathrm{Y}^{\prime}$ long (leftmost arrow) and $\mathrm{Y}^{\prime}$ short (rightmost arrow) telomeres. Pauses in $r r m 3 \Delta$ DNA are labeled 1-6 (see text). (HJ) Holliday junctions between internal $\mathrm{Y}^{\prime}$ long elements; (BU) bubble-containing replication intermediates for internal $\mathrm{Y}^{\prime}$ long elements. were the same in cells expressing the mutant K260A Rrm3p as in cells lacking Rrm3p, the ATPase/helicase activity of Rrm3p was needed for its role in replication of the III-L telomere (Fig. 5A).

If the $\mathrm{X} A R S$ on Chromosome III-L were used as an origin of DNA replication, replication of the SphI fragment would generate bubble-shaped replication intermediates. In wild-type cells, even longer exposure of the gel in Figure 5A (left panel) did not reveal bubble-shaped intermediates, consistent with the finding that this $A R S$ is not active in wild-type cells (Newlon et al. 1993). However, bubble-shaped intermediates were visible in rrm3 $\Delta$ DNA (Fig. 5A, second panel; longer exposure of same gel is shown in Fig. 5A, third panel; BU, bubbleshaped intermediates). Although the absence of Rrm3p enabled this normally inactive $A R S$ to fire, even in rrm3 $\Delta$ cells, the $\mathrm{X} A R S$ was not active at most of the Chromosome III-L telomeres as most of the III-L replication intermediates were simple forked molecules.

\section{Replication and recombination of $Y^{\prime} D N A$ is affected by Rrm3p}

About two-thirds of yeast telomeres bear one to four tandem copies of Y' (Fig. 5B; Chan and Tye 1983). Some Y' 
elements are right next to a telomere (terminal $\mathrm{Y}^{\prime}$; Fig. $5 \mathrm{~B}$, asterisk) and some are not (internal $\mathrm{Y}^{\prime}$; Fig. 5B, diamond). Short tracts of $\mathrm{C}_{1-3} \mathrm{~A} / \mathrm{TG}_{1-3}$ DNA are often found between tandem $\mathrm{Y}^{\prime}$ elements (Walmsley et al. 1984). $\mathrm{Y}^{\prime}$ has an $A R S$ that is active in at least some strains (Ferguson et al. 1991). When $\mathrm{Y}^{\prime} A R S$ s are inactive, ClaI fragments from internal (and terminal) $\mathrm{Y}^{\prime}$ elements are replicated by forks moving toward the telomere. If the $\mathrm{Y}^{\prime}$ $A R S$ on an internal $\mathrm{Y}^{\prime}$ element is active, its replication will begin in the center of the ClaI fragment and expand bidirectionally, producing bubble-shaped replication intermediates. The pattern of $\mathrm{Y}^{\prime}$ replication intermediates is complicated by the fact that $\mathrm{Y}^{\prime}$ comes in two sizes, $\mathrm{Y}^{\prime}$ long (6.7 kb) and $\mathrm{Y}^{\prime}$ short (5.2 kb; Louis and Haber 1990), and the size of both varies by the number of 36-bp repeats they contain (Horowitz and Haber 1984). In the strain used here for 2D gel analysis, most $\mathrm{Y}^{\prime}$ elements were $\mathrm{Y}^{\prime}$ longs (Fig. 5B).

To examine replication of $\mathrm{Y}^{\prime}$ telomeres, DNA was prepared from an asynchronous culture, digested with ClaI, and analyzed by $2 \mathrm{D}$ gels using $\mathrm{Y}^{\prime}$ probes (Fig. 5B). Digestion with ClaI releases a $5.3-\mathrm{kb}$ fragment from terminal $\mathrm{Y}^{\prime}$ long elements (Fig. 5B, asterisk) and a 6.2-kb fragment from internal $\mathrm{Y}^{\prime}$ long elements (Fig. 5B, diamond). In $\mathrm{Y}^{\prime}$ long telomeres, the $2 \mathrm{~N}$ spot was visible in both $r r m 3 \Delta$ and wild-type DNA, but the $2 \mathrm{~N} / 1 \mathrm{~N}$ ratio was $2.9 \pm 0.32$ fold higher in rrm $3 \Delta$ DNA (average \pm standard error; four independent experiments; Fig. 5B, $2 \mathrm{~N}$ spot denoted by arrows). In $\operatorname{rrm} 3 \Delta \mathrm{DNA}$, the $2 \mathrm{~N}$ spot was also visible at $\mathrm{Y}^{\prime}$ short telomeres (Fig. 5B, right panel, arrows). The threefold increase in the fraction of DNA in the $2 \mathrm{~N}$ spot for $\mathrm{Y}^{\prime}$-bearing telomeres in $r r m 3 \Delta$ cells was smaller than the $\sim 10$-fold increase at the left telomeres of Chromosome VII or III. However, as detailed below, there were many sites of replication pausing within $\mathrm{Y}^{\prime}$ DNA in addition to the pause within the telomere itself.

The pattern of $\mathrm{Y}^{\prime}$ intermediates in $\operatorname{rrm} 3 \Delta$ DNA was complicated. There were several structures that were detected only in rrm3 $\Delta$ DNA, such as Holliday junctions between internal $\mathrm{Y}^{\prime}$ elements (HJ; Fig. 5B, cartoon). The presence of Holliday junctions indicates that $\mathrm{Y}^{\prime}-\mathrm{Y}^{\prime}$ recombination was elevated in rrm $3 \Delta$ cells. An intermediate that behaved like an internal $\mathrm{Y}^{\prime}$ with an active origin was also detected only in rrm3 3 DNA (BU, bubble; Fig. $5 \mathrm{E}$, cartoon). Although the absence of Rrm3p increased the frequency of firing of the internal $\mathrm{Y}^{\prime} A R S$, the $\mathrm{Y}^{\prime} A R S$ was active in only a fraction of internal $\mathrm{Y}^{\prime}$ elements, as most internal $\mathrm{Y}^{\prime}$ elements were in simple forked intermediates, even in the rrm $3 \Delta$ strain (Fig. 5B, cartoon, diamond). There were additional sites of replication fork pausing in rrm $3 \Delta$ DNA (Fig. 5B, cartoon, 1-6). Sites 1 and 2 mapped near the $2 \mathrm{~N}$ spot on $\mathrm{Y}^{\prime}$ long and $\mathrm{Y}^{\prime}$ short telomeres. Site 3 mapped to the position of the $\mathrm{Y}^{\prime} A R S$ and the internal $\mathrm{C}_{1-3} \mathrm{~A} / \mathrm{TG}_{1-3}$ tract for internal $\mathrm{Y}^{\prime}$ long elements replicated by forks moving toward the telomere, as would be expected if all of the $\mathrm{Y}^{\prime} A R S$ s on the telomere were inactive. Site 4 mapped to the same region in internal $\mathrm{Y}^{\prime}$ long elements replicated by forks moving away from the telomere, as would be expected if the $A R S$ in a distal $\mathrm{Y}^{\prime}$ on the same telomere were active. Pausing was detected near the end of the ClaI fragments from internal $\mathrm{Y}^{\prime}$ long (site 5) and internal $\mathrm{Y}^{\prime}$ short (site 6) elements. The replication intermediates for cells expressing the mutant K260A Rrm3p were the same as in cells lacking Rrm3p, indicating that Rrm3p acts catalytically during $\mathrm{Y}^{\prime}$ replication.

Replication forks pause as they pass through internal tracts of $C_{1-3} A / T G_{1-3} D N A$, and this pausing is exacerbated in the absence of Rrm3p

Two models can explain the formation of the $2 \mathrm{~N}$ spot. First, the $2 \mathrm{~N}$ spot might arise from sister chromatids that are held together by unreplicated telomeric DNA. In this model, Rrm3p affects conventional, semiconservative replication of telomeric DNA (Fig. 6A, Model I). Alternatively, the $2 \mathrm{~N}$ spot could form after semiconservative replication of telomeres (Fig. 6A, Model II). Conventional replication of telomeres is followed by C-strand degradation, a process that generates single-strand $\mathrm{TG}_{1-3}$ tails on both ends of linear chromosomes (Wellinger et al. 1993a,b, 1996). In vitro, linear plasmids with $\mathrm{TG}_{1-3}$ tails can interact to form stable telomere-telomere associations (Fig. 6A, G-tail interaction step). If G-tail interactions formed between the ends of sister chromatids in vivo, they would generate intermediates that behaved like the $2 \mathrm{~N}$ spot in $2 \mathrm{D}$ gels. In this model, Rrm3p would be important for unwinding base-paired G-tails (Fig. 6A, Model II).

The two models cannot be distinguished readily by physical analysis of $2 \mathrm{~N}$-spot DNA. For example, brief digestion with mung bean nuclease degrades both replication forks and G-tail-associated telomeres (Wellinger et al. 1993b). However, if the first model were correct, Rrm3p might also affect the rate of fork movement through internal tracts of $\mathrm{C}_{1_{-3}} \mathrm{~A} / \mathrm{TG}_{1-3}$ DNA. To test this possibility, we used a strain having three 276-bp tracts of $\mathrm{C}_{1-3} \mathrm{~A} / \mathrm{TG}_{1-3}$ DNA inserted at the LYS2 locus, a site far from a telomere (Stavenhagen and Zakian 1994). The "triple tract" strain was constructed in such a way that there are $19 \mathrm{bp}$ of polylinker DNA between each $\mathrm{C}_{1-3} \mathrm{~A} / \mathrm{TG}_{1-3}$ tract. This $\sim 800-\mathrm{bp} \mathrm{C}_{1-3} \mathrm{~A} / \mathrm{TG}_{1-3}$ tract represses transcription of a nearby $U R A 3$ gene, albeit inefficiently compared with telomeres (Stavenhagen and Zakian 1994). Because silencing by internal $\mathrm{C}_{1-3} \mathrm{~A} / \mathrm{TG}_{1-3}$ tracts requires Raplp and the Sir complex (Stavenhagen and Zakian 1994), these tracts must bind many of the proteins found at telomeres, at least in some cells (see also Bourns et al. 1998).

DNA was prepared from wild-type and rrm3s cells bearing the $\sim 800-b p \mathrm{C}_{1-3} \mathrm{~A} / \mathrm{TG}_{1-3}$ tract within LYS2 (Fig. 6B). Pausing was seen at the $\mathrm{C}_{1-3} \mathrm{~A} / \mathrm{TG}_{1-3}$ tracts in both strains but in two independent experiments was about twofold higher in rrm $3 \Delta$ cells (ratio of the fraction of hybridization in the tracts over the signal in the $1 \mathrm{~N}$ spot for $\operatorname{rrm} 3 \Delta$ compared with wild type was 2.0 and 2.1). There were four discrete sites of pausing in both strains, suggesting that forks pause before and after passage through a $\mathrm{C}_{1-3} \mathrm{~A} / \mathrm{TG}_{1-3}$ tract. A 500-bp tract consisting solely of $\mathrm{C}_{1-3} \mathrm{~A} / \mathrm{TG}_{1-3}$ DNA and inserted within HIS4, 
A
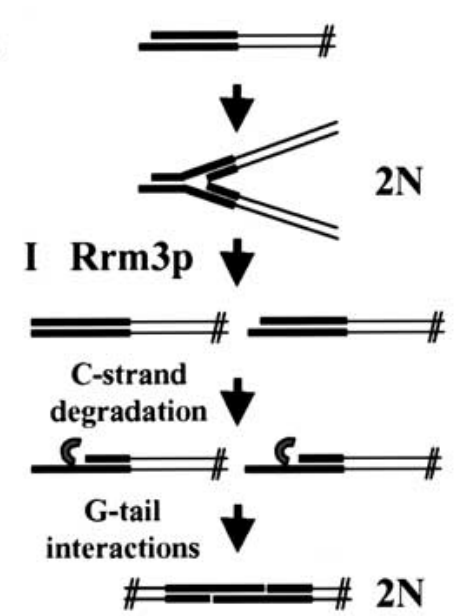

\section{Rrm3p †}

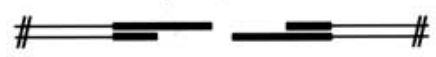

$\mathrm{C}$

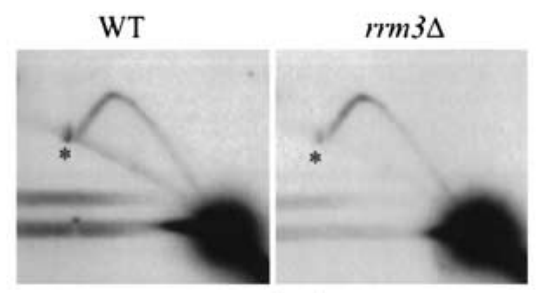

no tract
B
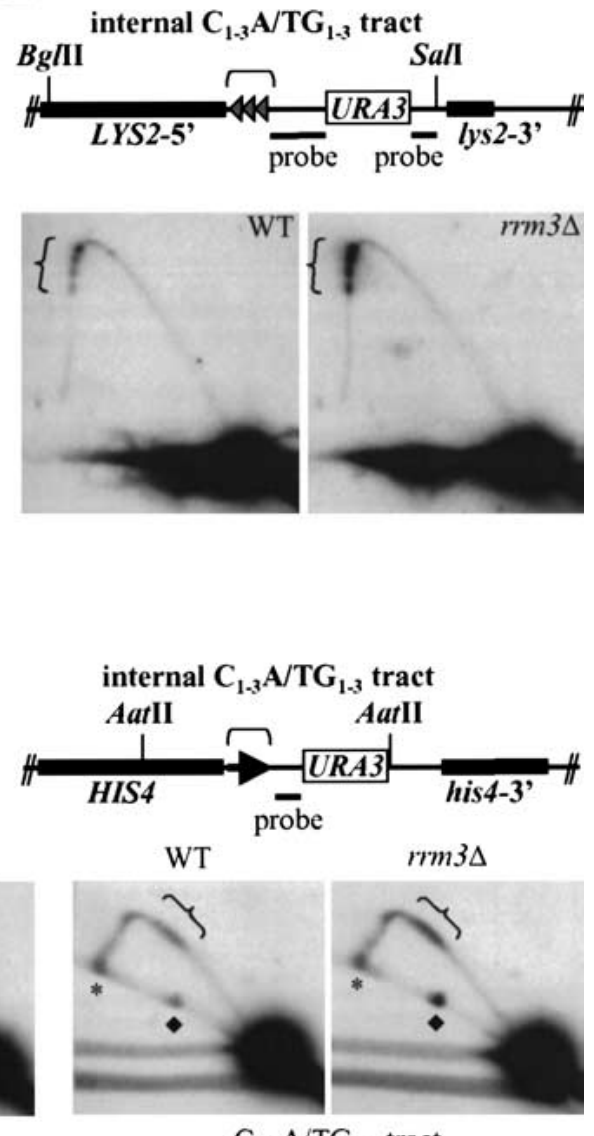

Yeast Rrm3p DNA helicase affects telomeres

Figure 6. Internal tracts of $\mathrm{C}_{1-3} \mathrm{~A} / \mathrm{TG}_{1-3}$ cause replication fork pausing, and this pausing is increased in an $r r m 3 \Delta$ strain. (A) The cartoon shows replication of a yeast telomere. The telomeric $\mathrm{C}_{1_{-3}} \mathrm{~A} /$ $\mathrm{TG}_{1-3}$ tract is in bold. There are two models that can explain the appearance of the $2 \mathrm{~N}$ spot. In Model I, the $2 \mathrm{~N}$ spot is formed by replication forks pausing before or within the $\mathrm{C}_{1-3} \mathrm{~A} / \mathrm{TG}_{1-3}$ tract. In this model, Rrm3p promotes semiconservative replication of telomeres. After DNA replication, the $\mathrm{C}$ strand of telomeric DNA is degraded to form long singlestrand $\mathrm{TG}_{1-3}$ tails (Wellinger et al. 1993a,b, 1996). If the $\mathrm{TG}_{1-3}$ tails on sister chromatids interacted by stable G-G base pairing, they would generate DNA that behaves like 2N-spot DNA. In Model II, Rrm3p would promote dissociation of Gbase-paired telomeres. Only the first model predicts that Rrm3p should promote replication through internal $\mathrm{C}_{1-3} \mathrm{~A} /$ $\mathrm{TG}_{1-3}$ tracts. $(B)$ Three 276-bp tracts of $\mathrm{C}_{1-}$ $3 \mathrm{~A} / \mathrm{TG}_{1-3} \mathrm{DNA}$, each separated from the adjacent tract by 19 bp of polylinker DNA, were inserted within the LYS2 locus (Stavenhagen and Zakian 1994). DNA from wild-type and $r r m 3 \Delta$ cells containing the $\mathrm{C}_{1-3} \mathrm{~A} / \mathrm{TG}_{1-3}$ tract was digested with BgIII and SalI, and examined by 2D gels. The probe detects a $7-\mathrm{kb}$ fragment. $(C)$ DNA from wild-type or rrm $3 \Delta$ cells with or without (no tract) a 500-bp $\mathrm{C}_{1-3} \mathrm{~A} /$ $\mathrm{TG}_{1-3}$ tract inserted within HIS4 was digested with AatII and analyzed by $2 \mathrm{D}$ gels, using the indicated probe. The probe detects a 3.6-kb Aat II fragment in the no-tract control strains and a 4.1-kb Aat II fragment in strains with the $\mathrm{C}_{1-3} \mathrm{~A} / \mathrm{TG}_{1-3}$ tract. The asterisks mark an 8-kb AatII fragment that cross-reacts with the hybridization probe. This cross-reacting band falls fortuitously near the position of $2 \mathrm{~N}$-spot DNA in the strains with the $\mathrm{C}_{1-3} \mathrm{~A} / \mathrm{TG}_{1-3}$ tract. The linear fragment of $\sim 5.5 \mathrm{~kb}$ that is marked by a diamond is seen only in the presence of the $0.5-\mathrm{kb} \mathrm{C}_{1-3} \mathrm{~A} / \mathrm{TG}_{1-3}$ tract. Because its abundance is proportional to the amount of pausing at the $\mathrm{C}_{1-3} \mathrm{~A} / \mathrm{TG}_{1-3}$ tract, it is probably caused by breakage of stalled replication intermediates immediately ahead of the replication fork as in Figure 5A. In panels $B$ and $C$, brackets indicate the position of the $\mathrm{C}_{1-3} \mathrm{~A} / \mathrm{TG}_{1-3}$ tracts.

$\sim 65 \mathrm{~kb}$ from the left telomere of Chromosome III, also slowed replication fork progression (Fig. 6C). In two independent experiments, this pausing was increased about twofold (ratios of 1.7 and 1.9) in the rrm3 3 strain. We speculate that Rrm3p-dependent pausing was less dramatic at internal tracts of $\mathrm{C}_{1-3} \mathrm{~A} / \mathrm{TG}_{1-3}$ DNA than at telomeres because internal tracts are less likely to assemble into a non-nucleosomal chromatin structure as inferred from their reduced ability to repress transcription of a nearby gene (Stavenhagen and Zakian 1994). In the absence of the $\mathrm{C}_{1-3} \mathrm{~A} / \mathrm{TG}_{1-3}$ tract, there was no Rrm3p-dependent pausing in the 3.6-kb restriction fragment that contains HIS4 (Fig. 6C, no tract controls). Because $\mathrm{Rrm} 3 \mathrm{p}$ is needed for fork progression through internal $\mathrm{C}_{1-3} \mathrm{~A} / \mathrm{TG}_{1-3}$ tracts, the most parsimonious explanation is that $\mathrm{Rrm} 3 \mathrm{p}$ also promotes fork progression through duplex telomeric DNA (Fig. 6, Model I). However, we cannot exclude the possibility that Rrm3p also acts after conventional DNA replication to promote separation of G-tail-G-tail interactions (Fig. 6, Model II).

\section{Rrm3p is associated with telomeric DNA in vivo}

Because helicases affect multiple processes, Rrm3p could affect telomere replication directly or indirectly. If Rrm3p affects telomere replication directly, it should be telomere-associated in vivo. To address this possibility, we used chromatin immunoprecipitation (Fig. 7A). Chromatin was cross-linked in vivo with formaldehyde, sheared, and precipitated with either protein-A-purified preimmune antibodies (rabbit IgG) or antigen-affinitypurified anti-Rrm3p antibodies ( $\alpha$-Rrm3p; Fig. 7A). As a positive control, chromatin was also precipitated with an anti-Raplp serum $(\alpha-R a p l p)$, as Raplp is the major telomere-binding protein in yeast (Conrad et al. 1990; Wright and Zakian 1995). The cross-links in the immunoprecipitates were reversed, DNA was purified, and then amplified by the polymerase chain reaction (PCR) using primers for a 233-bp portion of the subtelomeric $\mathrm{Y}^{\prime}$ element that is $30 \mathrm{bp}$ upstream of the $\mathrm{C}_{1-3} \mathrm{~A} / \mathrm{TG}_{1-3}$ tracts. As a control, primers that amplify a 131-bp frag- 
Figure 7. Rrm3p is associated with telomeric DNA in vivo and has a modest effect on TPE. (A) Chromatin was prepared from otherwise isogenic wild-type or rrm $3 \Delta$ cells that had been cross-linked (+ cross-link) or not (- cross-link) with formaldehyde in vivo. Immunoprecipitation was carried out using either protein-A-purified preimmune IgG (rabbit IgG), a polyclonal Raplp antiserum ( $\alpha$-Raplp; Conrad et al. 1990), or affinity-purified anti-Rrm3p polyclonal antibodies (Ivessa et al. 2000). The DNA in the precipitate was PCR-amplified for 28 cycles using $\mathrm{Y}^{\prime}$ primers that detect a 233-bp portion of the subtelomeric $\mathrm{Y}^{\prime}$ element that begins $30 \mathrm{bp}$ upstream of the terminal $\mathrm{C}_{1-3} \mathrm{~A} /$ $\mathrm{TG}_{1-3}$ tracts or for 31 cycles using ACT1 primers. The PCR products were separated in a $2.3 \%$ agarose gel and visualized by staining with ethidium bromide. PCR amplification of the input DNA with telomeric primers is also shown (Input). Although Rrm3p association with telomeric DNA was eliminated in the absence of in vivo cross-linking, some Raplp association with telomeric DNA was detected in the no cross-linking control. $(B)$ TPE was measured in a strain with URA3 next to the left telomere of Chromosome VII (Gottschling et al. 1990) and ADE2 next to the right telomere of Chromosome V (Wiley and Zakian 1995). Wild-type or rrm3s cells were plated on media containing low amounts of adenine, and the color of the resulting colonies was examined.

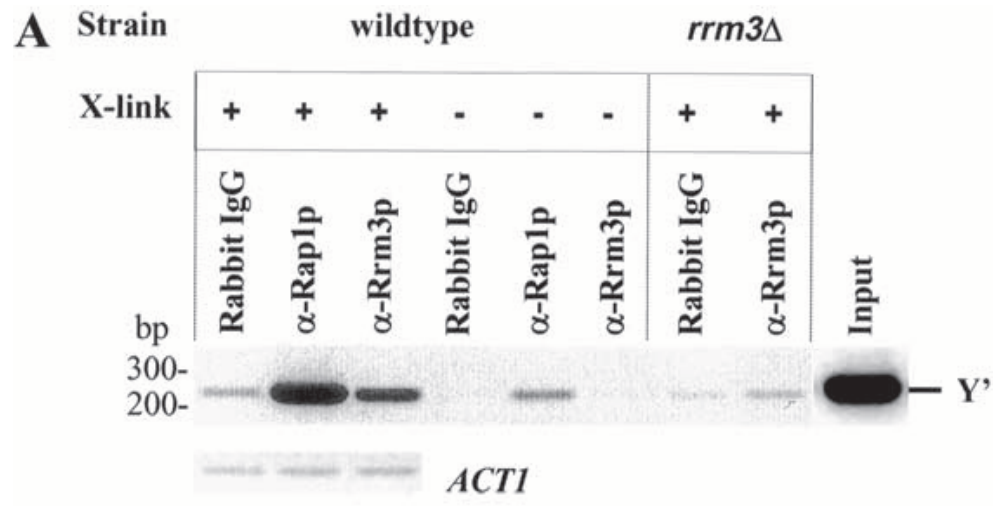

B

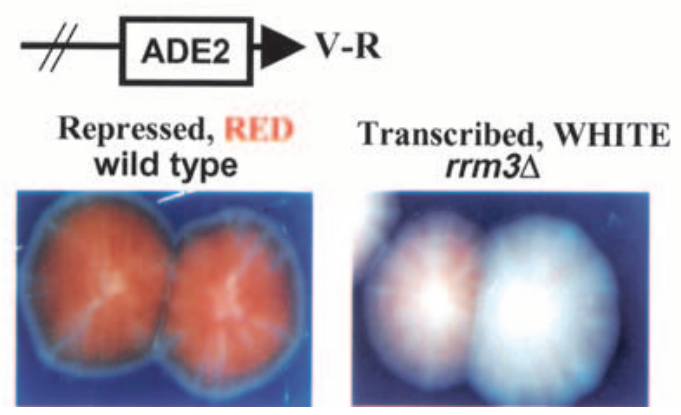

fold lower in rrm3s cells (average fraction of $\mathrm{FOA}^{\mathrm{R}}$ cells \pm S.D. was $0.54 \pm 0.12$ in wild-type cells and $0.15 \pm 0.047$ in $r r m 3 \Delta$ cells). Therefore, Rrm3p is required for wild-type levels of TPE, but its effects on TPE are modest.

\section{Discussion}

Rrm3p is a $5^{\prime}$ to $3^{\prime}$ DNA helicase (Fig. 1) that affects progression of replication forks through telomeric and subtelomeric DNA (Figs. 3-6) as well as telomere length (Fig. 2A), the ability of Piflp to inhibit telomerase-mediated telomere addition (Fig. 2B), and telomere position effect (Fig. 7B). Rrm3p was telomere-associated in vivo (Fig. 7A), arguing that its effects on telomeres are likely direct. Point mutations in the ATP-binding Walker A box that eliminate the activity of other helicases had the same effects on telomere replication as null alleles of RRM3 (Figs. 3C, 5). Therefore, Rrm3p acts catalytically during replication of telomeric DNA.

A new intermediate in telomere replication, the $2 \mathrm{~N}$ spot, is described in this study. The $2 \mathrm{~N}$ spot was seen at the modified VII-L telomere (Figs. 3,4 ) as well as at natural X-(Fig. 5A) and $\mathrm{Y}^{\prime}$-bearing telomeres (Fig. 5B). The 2N spot had the mass and structure expected for sister chromatids held together within the telomeric $\mathrm{C}_{1-3} \mathrm{~A} / \mathrm{TG}_{1-3}$ tract. This interpretation was confirmed by showing that the $2 \mathrm{~N}$ spot at the Chromosome VII-L telomere was lost upon BamHI digestion (Fig. 3B). As expected for a replication intermediate, the $2 \mathrm{~N}$ spot was cell cycle regulated, appearing and disappearing at specific times in the cell cycle (Fig. 4). In asynchronous cells, the $2 \mathrm{~N}$ spot in 
rrm3s cells was 10 times more abundant than in wildtype cells. In synchronous cells, it persisted for a longer amount of time in $r r m 3 \Delta$ than in wild-type cells (Fig. 4C). These data are consistent with a model in which the $2 \mathrm{~N}$ spot is a normal intermediate in telomere replication whose half-life is increased in the absence of Rrm3p, suggesting that the Rrm3p helicase plays a role in its processing.

In addition to its effects on fork progression through telomeric $\mathrm{C}_{1-3} \mathrm{~A} / \mathrm{TG}_{1-3}$ tracts, loss of Rrm3p exacerbated the natural pausing at the silent $A R S$ within the subtelomeric X on Chromosome III-L (Fig. 5A) and revealed new replication pauses within the subtelomeric region of Chromosome VII-L (Fig. 3C, asterisk) and at multiple sites within $\mathrm{Y}^{\prime}$ DNA, including two that mapped to a region that contains both an inactive $A R S$ and an internal $\mathrm{C}_{1-3} \mathrm{~A} / \mathrm{TG}_{1-3}$ tract (Fig. 5B). Cells lacking Rrm3p also had an increased abundance of Holliday junctions between tandem $\mathrm{Y}^{\prime}$ elements (Fig. 5B) and DNA breakage at specific sites (Figs. 5A, 6C). Similarly, loss of Rrm3p results in replication pausing at specific sites within rDNA, including at silent replication origins and regulatory regions for transcription of the $35 \mathrm{~S}$ and $5 \mathrm{~S}$ rRNAs. Recombination and DNA breakage are also elevated in rDNA in rrm3s cells (Ivessa et al. 2000). Likewise, DNA breakage accompanies replication fork stalling in bacteria (see, e.g., Seigneur et al. 1998). The increased breakage and recombination seen in the absence of Rrm3p are likely secondary consequences of faulty DNA replication.

Although Rrm3p affects fork progression in rDNA (Ivessa et al. 2000) and telomeres (this paper), there are many regions that are unaffected by loss of Rrm3p. As assayed by $2 \mathrm{D}$ gels, replication of a $4.5-\mathrm{kb}$ region that accounts for half of the rDNA repeat unit (Ivessa et al. 2000), a $7-\mathrm{kb}$ region containing $L Y S 2$, and a $3.6-\mathrm{kb}$ region containing HIS4 (Fig. 6) are unaffected in a rrm3s strain. Nonetheless, Rrm3p activity is not limited to the rDNA and telomeres. For example, Rrm $3 p$ also affected fork progression at internal tracts of $\mathrm{C}_{1-3} \mathrm{~A} / \mathrm{TG}_{1-3} \mathrm{DNA}$, even when these tracts were far from a telomere (Fig. 6).

In addition to defects in telomere replication, Rrm3p affected telomere length (Fig. 2), TPE (Fig. 7B), and the frequency of firing of subtelomeric $\mathrm{X}$ and $\mathrm{Y}^{\prime}$ replication origins (Fig. 5). Because these effects were modest, they may be secondary to the delay in conventional telomere replication. For example, stalling of replication forks within telomeric DNA might cause replication fork slippage, which, in turn, could bring about telomere lengthening. Firing of latent replication origins in $\mathrm{X}$ and $\mathrm{Y}^{\prime}$ DNA (Fig. 5) probably results from the delayed arrival of replication forks to subtelomeric regions.

The data in this paper have implications for helicase subfamilies. As expected from their high level of sequence similarity, Rrm3p and Piflp are both $5^{\prime}$ to $3^{\prime}$ DNA helicases (Fig. 1D). Although both helicases act at telomeres, they affect different steps in telomere replication. Rrm3p promoted conventional, semiconservative replication of telomeric DNA (Figs. 3-6), whereas Pif1p inhibits telomerase (Zhou et al. 2000; Myung et al.
2001). By itself, Rrm3p did not affect the ability of telomerase to add telomeres to double strand breaks, and its deletion partially suppressed Piflp's inhibition of these events (Fig. 2B). Piflp had no effect on conventional replication of telomeres as assayed by $2 \mathrm{D}$ gels (data not shown). Thus, the sequence similarity that defines the Pif1 subfamily of DNA helicases most likely reflects their ability to recognize or be recruited to common DNA substrates.

Rrm3p, a 5' to 3' DNA helicase, acts catalytically to promote fork progression at rDNA (Ivessa et al. 2000) and telomeres (this paper). Several models are consistent with this behavior. First, Rrm $3 p$ might be a regionalspecific replicative helicase that acts at both telomeres and rDNA. However, replication of rDNA and telomeres is slowed but not prevented in its absence, and fork progression throughout the rDNA also requires the MCM complex (J. Bessler and V.A. Zakian, unpubl.). Thus, Rrm3p is unlikely to be the sole replicative helicase, at least for rDNA. Alternatively, Rrm3p might facilitate passage of replication forks through large protein-DNA complexes. This model is consistent with the fact that sites that display Rrm3p-dependent pauses, including telomeres (Figs. 3-5), internal tracts of $\mathrm{C}_{1-3} \mathrm{~A} / \mathrm{TG}_{1-3}$ DNA (Fig. 6), the replication fork barrier (RFB) in the rDNA (Ivessa et al. 2000), highly transcribed promoters (Ivessa et al. 2000), and silent replication origins (Fig. 5; Ivessa et al. 2000), are assembled into large protein-DNA complexes (Wright et al. 1992; Santocanale and Diffley 1996; Bourns et al. 1998). For example, Rrm3p might be part of a chromatin-remodeling machinery that makes such regions accessible to the conventional DNA replication machinery, or Rrm3p might be required to restart forks that collapse as they attempt to pass through these regions.

Replication fork collapse is a common occurrence in both prokaryotes and eukaryotes (for review, see Cox et al. 2000; Marians 2000; Rothstein et al. 2000). For example, in Escherichia coli, both DNA damage and DNAprotein complexes are thought to trigger fork collapse, resulting in the demise of $\sim 30 \%$ of the replication forks emanating from oriC. Two bacterial DNA helicases, PriA and Rep, appear to have roles in replication fork restart. Although eukaryotic proteins with roles in fork restart have not been identified, the Rrm3p DNA helicase has many of the characteristics expected for such an activity.

\section{Materials and methods}

\section{Expression, purification, and activities of Rrm $3 p \Delta N$}

To make a truncated version of Rrm3p, a 1587-bp fragment of $R R M 3$ that began at amino acid 194 and went to the stop codon was PCR-amplified from a clone containing full-length RRM3 and inserted at the BamHI site of pEG(KT) (Mitchell et al. 1993) to generate $\mathrm{pEG}(\mathrm{KT})-\mathrm{Rrm} 3 \Delta \mathrm{N}$. In $\mathrm{pEG}(\mathrm{KT})$, proteins are expressed as carboxy-terminal fusions to GST and are expressed under the control of the galactose-inducible GAL1 promoter. pEG(KT)-Rrm $3 \Delta \mathrm{N}$ was transformed into the protease-deficient 
S. cerevisiae BCY123 strain (Bennett et al. 1998). Expression was carried out using minor modifications of the methods described in Bennett et al. (1998). Cells were harvested, washed, and resuspended in 8-vol of lysis buffer $(50 \mathrm{mM}$ Tris at $\mathrm{pH} 7.8$ $500 \mathrm{mM} \mathrm{NaCl}, 4 \mathrm{mM} \mathrm{MgCl}{ }_{2}, 40 \mu \mathrm{g} / \mathrm{mL}$ DNase I, $10 \mathrm{mM}$ dithiothreitol, $0.1 \%$ Triton X-100, 0.004\% 1-octanol) and a mixture of protease inhibitors. The resuspended cells were disrupted by passing them twice through a homogenizer. After centrifugation, the supernatant was brought to $50 \%$ saturation with ammonium sulfate. The precipitate was collected by centrifugation, dissolved in $20 \mathrm{~mL}$ of PBS supplemented with $5 \mathrm{mM}$ dithiothreitol, $0.5 \%$ Triton X-100, 0.001\% 1-octanol, and the mixture of protease inhibitors. The soluble fraction recovered by centrifugation was loaded onto a Glutathione sepharose 4B (Pharmacia) column equilibrated with PBS. Protein was eluted with $20 \mathrm{~mL}$ of elution buffer $(50 \mathrm{mM}$ Tris at $\mathrm{pH} 8.8,30 \mathrm{mM}$ reduced glutathione, $50 \mathrm{mM} \mathrm{NaCl}, 10 \mathrm{mM}$ dithiothreitol, $0.1 \%$ Triton X-100, 0.001\% 1-octanol). The elution was loaded onto a 10-mL Q-sepharose column (Pharmacia) equilibrated with 50 $\mathrm{mM}$ Tris- $\mathrm{HCl}$ buffer at $\mathrm{pH} 7.8(50 \mathrm{mM} \mathrm{NaCl}, 1 \mathrm{mM}$ EDTA, 1 $\mathrm{mM}$ dithiothreitol, $0.002 \%$ Triton $\mathrm{X}-100$ ) at a flow rate of 30 $\mathrm{mL} / \mathrm{h}$. The column was washed with the equilibration buffer, and eluted with a linear $\mathrm{NaCl}$ gradient. During its purification, $\operatorname{Rrm} 3 \mathrm{p} \Delta \mathrm{N}$ was followed by immunoblot analysis using the antiRrm3p serum described in Ivessa et al. (2000). Rrm3p $\Delta$ N eluted from the Q-sepharose column between 150 and $200 \mathrm{mM} \mathrm{NaCl}$.

The ATPase and helicase assays were $20-\mu \mathrm{L}$ reactions containing $200 \mathrm{ng}$ of recombinant Rrm $3 \mathrm{p} \Delta \mathrm{N}$ or $100 \mathrm{ng}$ of recombinant Piflp (purified as described in Zhou et al. 2000). The ATPase assays were in ATPase buffer ( $25 \mathrm{mM}$ HEPES at pH 7.6, $5 \mathrm{mM} \mathrm{MgCl}_{2}, 2 \mathrm{mM}$ ATP, $1 \mathrm{mM}$ dithiothreitol, $100 \mu \mathrm{g} / \mathrm{mL}$ BSA) at $37^{\circ} \mathrm{C}$ for $30 \mathrm{~min}$. Each reaction contained $0.5 \mu \mathrm{Ci}$ of $\left[\gamma^{-32} \mathrm{P}\right] \mathrm{ATP}$ and $0.2 \mu \mathrm{g} / \mu \mathrm{L}$ M13mp18 single-stranded DNA. Reactions were stopped by the addition of $1 \mu \mathrm{L}$ of $0.5 \mathrm{M}$ EDTA, and $0.5 \mu \mathrm{L}$ of each reaction was spotted on polyethylimine (PEI) cellulose plate (Baker). The plate was developed in $0.8 \mathrm{M} \mathrm{LiCl}$, and dried with hot air. For helicase assays, the 5' 25-mer oligonucleotide was 5'-GTTGTAAAACGACGGCCAGTGAATT-3' and the 36-mer oligonucleotide was $5^{\prime}$-CGTAATCATGGT CATAGCTGTTTCCTGTGTGAAATT-3'. For the helicase assay, 2.5 pmole of both the ${ }^{32} \mathrm{P}$-end-labeled 25 -mer and $36-$ mer oligonucleotides were annealed in a $75-\mu \mathrm{L}$ reaction mixture with 2.5 pmole of single-stranded M13mp7 DNA that had been linearized by digestion with EcoRI. The annealed substrates were purified with the Chroma Spin-1000 column (Clontech). The $20-\mu \mathrm{L}$ helicase activity assays had 30 fmole of DNA substrate in $20 \mathrm{mM}$ HEPES (pH 7.6), $5 \mathrm{mM} \mathrm{MgAc}_{2}, 4 \mathrm{mM}$ ATP, 100 $\mu \mathrm{g} / \mathrm{mL}$ BSA, $5 \%$ glycerol, $1 \mathrm{mM} \mathrm{DTT}$, and were carried out at $37^{\circ} \mathrm{C}$ for $10 \mathrm{~min}$. Reactions were stopped by addition of $5 \mu \mathrm{L}$ of a stop buffer (50 mM Tris at $\mathrm{pH} 7.8,100 \mathrm{mM}$ EDTA, 2\% SDS). Products were analyzed by electrophoresis in a $10 \%$ polyacrylamide gel (89 mM Tris borate at pH 8.3, 2 mM EDTA).

\section{Strains, DNA preparation, and gel electrophoresis}

The two $\operatorname{rrm} 3 \Delta$ alleles used in this paper were both precise deletions of the $R R M 3$ ORF that were made by PCR, insertion of HIS3 (TPE experiments), or TRP1 (all other experiments) and introduced into diploid cells by integrative transformation. Haploid $\mathrm{Trp}^{+}$or $\mathrm{His}^{+}$segregants were identified after sporulation and tetrad dissections. The rrm3-K260A allele was described in Ivessa et al. (2000) and the pif1 $\Delta$ allele in Schulz and Zakian (1994). The rrm3s pif1s strain was made by mating singly mutant strains and sporulating the resulting diploid. Telomere length analysis was carried out in both the VPS106 (Schulz and Zakian 1994) and YPH499 (Sikorski and Hieter
1989) backgrounds with similar results. Replication intermediates were analyzed in the VPS106 background. The left telomere of Chromosome VII was modified as in Gottschling et al. (1990). The strain with the triple tract of $\mathrm{C}_{1-3} \mathrm{~A} / \mathrm{TG}_{1-3}$ is YJS-TTL-URA (Stavenhagen and Zakian 1994). The strain containing the $\mathrm{C}_{1-3} \mathrm{~A} / \mathrm{TG}_{1-3}$ tract at HIS4 was generously provided by S.-C. Teng (Princeton University, NJ). It was made using a HpaI-linearized version of pRS306 that had a portion of HIS4 (bp 14012400 ) inserted at the $\mathrm{KpnI}$ site and an $~ 500-b p \mathrm{C}_{1-3} \mathrm{~A} \mathrm{TG}_{1-3}$ tract, cloned from a recombinationally lengthened natural telomere inserted at the EcoRI site.

For most experiments, cells were grown to a density of $1-2 \times 10^{7}$ cells $/ \mathrm{mL}$ at $30^{\circ} \mathrm{C}$. Cell growth was stopped by putting cells on ice in the presence of $0.1 \% \mathrm{NaN}_{3}$. For the synchrony experiment, cells were arrested with $5 \mathrm{mg} / \mathrm{L} \alpha$ factor (Sigma) at $22^{\circ} \mathrm{C}$ for $\sim 3 \mathrm{~h}$. Cells were released from the $\mathrm{G}_{1}$ arrest by adding pronase to $125 \mu \mathrm{g} / \mathrm{mL}$, then were grown at $22^{\circ} \mathrm{C}$ with samples taken at 15 -min intervals. Cells were processed for FACs analysis using $1 \mu \mathrm{M}$ SYTOX Green (Molecular Probes) after fixation in $70 \%$ ethanol and digestion with $0.25 \mathrm{mg} / \mathrm{mL}$ RNase A and 1 $\mathrm{mg} / \mathrm{mL}$ proteinase $\mathrm{K}$ (Sigma). DNA was isolated from yeast nuclei obtained by a glass bead procedure (Huberman et al. 1987). To observe replication intermediates, minor modification of the neutral/neutral 2D gel electrophoresis method (Brewer and Fangman 1987) was used. Typically, the first dimension was $0.35 \%(\mathrm{w} / \mathrm{v})$ agarose in $1 \times$ TBE (Tris borate-EDTA) at 0.6-0.7 $\mathrm{V} / \mathrm{cm}$ at room temperature for $45-48 \mathrm{~h}$. The second dimension was $0.9 \%(\mathrm{w} / \mathrm{v}) 1 \times \mathrm{TBE}$ agarose gels plus $0.3 \mu \mathrm{g} / \mathrm{mL}$ ethidium bromide at $2.6-3 \mathrm{~V} / \mathrm{cm}$ at $4^{\circ} \mathrm{C}$ for $18-24 \mathrm{~h}$. To examine $\mathrm{Y}^{\prime}$ intermediates (Fig. 5D), the first-dimensional gel was run for $60 \mathrm{~h}$ and the second-dimensional gel for $48 \mathrm{~h}$. Quantification of autoradiograms was performed by storage phosphor imaging using the Molecular Dynamics 400A PhosphorImager. Image analysis was performed using the ImageQuant software. As a background correction, the intrinsic parameter LocalMedian was applied.

\section{Other assays}

The rate of forming new telomeres was determined in the VPS106 background using the assay described in Schulz and Zakian (1994) except that a slightly different YAC, YAC-VS9, was used. Chromatin immunoprecipitations were carried out with minor modifications of the methods described in Hecht et al. (1996) in the YPH499 background (Sikorski and Hieter 1989). Sequences for primers are available upon request. The $\mathrm{Y}^{\prime}$ primers are $240 \mathrm{bp}$ and $33 \mathrm{bp}$ away from the telomere. A $20-\mu \mathrm{L}$ aliquot of the $50-\mu \mathrm{L}$ PCR products was resolved in a $2.3 \%$ agarose gel containing $200 \mu \mathrm{g} / \mathrm{L}$ of ethidium bromide. A twofold dilution series of the PCR products was loaded in the same gel to estimate the fold enrichment of telomeric $\mathrm{Y}^{\prime}$ DNA in the immunoprecipitates.

TPE values were determined in the YPH499 background (Sikorski and Hieter 1989) in a strain with URA3 next to the left telomere of Chromosome VII (Gottschling et al. 1990), and ADE2 at the right telomere of Chromosome $\mathrm{V}$ (Wiley and $\mathrm{Za}$ kian 1995). To determine the percentage of $\mathrm{FOA}^{\mathrm{R}}$ cells, single colonies growing on $\mathrm{YC}$ plates were cored out and resuspended in water, and 10-fold serial dilutions were plated on YC-URA, $\mathrm{YC}$, and FOA plates.

\section{Acknowledgments}

We thank J. Bessler for constructing YCplac111-RRM3 and YCplac111-rrm3K260A and S.-C. Teng for constructing the strain 
with the $\mathrm{C}_{1-3} \mathrm{~A} / \mathrm{TG}_{1-3}$ tract at HIS4. We thank A. Taggart for help with the synchrony experiments. We also thank J. Bessler, B. Lenzmeier, M. Mateyak, J. Torres, and L. Vega for comments on the manuscript. We thank the National Institutes of Health (R37 GM26938), the Austrian NSF, and the Leukemia and Lymphoma Society (A.S.I.), the American Cancer Society (V.P.S.), and the National Institutes of Health (E.K.M.) for financial support.

The publication costs of this article were defrayed in part by payment of page charges. This article must therefore be hereby marked "advertisement" in accordance with 18 USC section 1734 solely to indicate this fact.

\section{References}

Bennett, R.J., Sharp, J.A., and Wang, J.C. 1998. Purification and characterization of the Sgs1 DNA helicase activity of Saccharomyces cerevisiae. J. Biol. Chem. 273: 9644-9650.

Bessler, J.B., Torres, J.Z., and Zakian, V.A. 2001. The Piflp subfamily of helicases: Region specific DNA helicases. Trends Cell Biol. 11: 60-65.

Bourns, B.D., Alexander, M.K., Smith, A.M., and Zakian, V.A. 1998. Sir proteins, Rif proteins and Cdc13p bind Saccharomyces telomeres in vivo. Mol. Cell. Biol. 18: 5600-5608.

Brewer, B.J. and Fangman, W.L. 1987. The localization of replication origins on ARS plasmids in S. cerevisiae. Cell 51: 463-471.

Button, L.L. and Astell, C.R. 1986. The Saccharomyces cerevisiae chromosome III left telomere has a type $\mathrm{X}$, but not a type $\mathrm{Y}^{\prime}$, ARS region. Mol. Cell. Biol. 6: 1352-1356.

Chan, C.S.M. and Tye, B.-K. 1983. Organization of DNA sequences and replication origins at yeast telomeres. Cell 33: $563-573$.

Conrad, M.N., Wright, J.H., Wolf, A.J., and Zakian, V.A. 1990. RAP1 protein interacts with yeast telomeres in vivo: Overproduction alters telomere structure and decreases chromosome stability. Cell 63: 739-750.

Cox, M.M., Goodman, M.F., Kreuzer, K.N., Sherratt, D.J., Sandler, S.J., and Marians, K.J. 2000. The importance of repairing stalled replication forks. Nature 404: 37-41.

Ferguson, B.M., Brewer, B.J., Reynolds, A.E., and Fangman, W.L. 1991. A yeast origin of replication is activated late in S phase. Cell 65: 507-515.

Formosa, T. and Nittis, T. 1999. Dna2 mutants reveal interactions with DNA polymerase $\alpha$ and Ctf 4 , a Pol $\alpha$ accessory factor, and show that full Dna2 helicase activity is not essential for growth. Genetics 151: 1459-1470.

Gottschling, D.E., Aparicio, O.M., Billington, B.L., and Zakian, V.A. 1990. Position effect at $S$. cerevisiae telomeres: Reversible repression of Pol II transcription. Cell 63: 751-762.

Gravel, S., Larrivee, M., Labrecque, P., and Wellinger, R.J. 1998. Yeast $\mathrm{Ku}$ as a regulator of chromosomal DNA end structure. Science 280: 741-744.

Hecht, A., Strahl-Bolsinger, S., and Grunstein, M. 1996. Spreading of transcriptional repressor SIR3 from telomeric heterochromatin. Nature 383: 92-96.

Horowitz, H. and Haber, J.E. 1984. Subtelomeric regions of yeast chromosomes contain a 36 base-pair tandemly repeated sequence. Nucleic Acids Res. 12: 7105-7121.

Huberman, J.A., Spotila, L.D., Nawotka, K.A., El-Assouli, S.M., and Davis, L.R. 1987. The in vivo replication origin of the yeast $2 \mu \mathrm{m}$ plasmid. Cell 51: 473-481.

Ivessa, A.S., Zhou, J.-Q., and Zakian, V.A. 2000. The Saccharomyces Piflp DNA helicase and the highly related Rrm3p have opposite effects on replication fork progression in ribo- somal DNA. Cell 100: 479-489.

Keil, R.L. and McWilliams, A.D. 1993. A gene with specific and global effects on recombination of sequences from tandemly repeated genes in Saccharomyces cerevisiae. Genetics 135: 711-718.

Lahaye, A., Leterme, S., and Foury, F. 1993. PIF1 DNA helicase from Saccharomyces cerevisiae. Biochemical characterization of the enzyme. J. Biol. Chem. 268: 26155-26161.

Lea, D.E. and Coulson, C.A. 1949. The distribution of the numbers of mutants in bacterial populations. J. Genet. 49: 264285

Louis, E.J. and Haber, J.E. 1990. Mitotic recombination among subtelomeric $\mathrm{Y}^{\prime}$ repeats in Saccharomyces cerevisiae. Genetics 124: 547-559.

Lundblad, V. and Szostak, J.W. 1989. A mutant with a defect in telomere elongation leads to senescence in yeast. Cell 57: 633-643.

Mangahas, J.L., Alexander, M.K., Sandell, L.L., and Zakian, V.A 2001. Repair of chromosome ends after telomere loss in Saccharomyces. Mol. Biol. Cell 12: 4078-4089.

Marcand, S., Brevet, V., Mann, C., and Gilson, E. 2000. Cell cycle restriction of telomere elongation. Curr. Biol. 10: 487490.

Marians, K.J. 2000. PriA-directed replication fork restart in Escherichia coli. Trends Biochem. Sci. 25: 185-189.

Martin, S.G., Laroche, T., Suka, N., Grunstein, M., and Gasser, S.M. 1999. Relocalization of telomeric Ku and SIR proteins in response to DNA strand breaks in yeast. Cell 97: 621-633.

McCarroll, R.M. and Fangman, W.L. 1988. Time of replication of yeast centromeres and telomeres. Cell 54: 505-513.

Mitchell, D.A., Marshall, T.K., and Deschenes, R.J. 1993. Vectors for the inducible overexpression of glutathione S-transferase fusion proteins in yeast. Yeast 9: 715-723.

Myung, K., Chen, C., and Kolodner, R.D. 2001. Multiple pathways cooperate in the suppression of genome instability in Saccharomyces cerevisiae. Nature 411: 1073-1076.

Newlon, C.S., Collins, I., Dershowitz, A., Deshpande, A.M., Greenfeder, S.A., Ong, L.Y., and Theis, J.F. 1993. Analysis of replication origin function on Chromosome III of Saccharomyces cerevisiae. Cold Spring Harbor Symp. Quant. Biol. 58: $415-423$

Pluta, A.F., Dani, G.M., Spear, B.B., and Zakian, V.A. 1984 Elaboration of telomeres in yeast: Recognition and modification of termini from Oxytricha macronuclear DNA. Proc. Natl. Acad. Sci. 81: 1475-1479.

Rothstein, R., Michel, B., and Gangloff, S. 2000. Replication fork pausing and recombination or "gimme a break." Genes \& Dev. 14: 1-10.

Santocanale, C. and Diffley, J.F. 1996. ORC- and Cdc6-dependent complexes at active and inactive chromosomal replication origins in Saccharomyces cerevisiae. EMBO J. 15: 66716679.

Schulz, V.P. and Zakian, V.A. 1994. The Saccharomyces PIF1 DNA helicase inhibits telomere elongation and de novo telomere formation. Cell 76: 145-155.

Seigneur, M., Bidnenko, V., Ehrlich, S.D., and Michel, B. 1998 RuvAB acts at arrested replication forks. Cell 95: 419-430.

Shiratori, A., Shibata, T., Arisawa, M., Hanaoka, F., Murakami, Y., and Eki, T. 1999. Systematic identification, classification, and characterization of the open reading frames which encode novel helicase-related proteins in Saccharomyces cerevisiae by gene disruption and Northern analysis. Yeast 15: 219-253.

Sikorski, R.S. and Hieter, P. 1989. A system of shuttle vectors and yeast host strains designed for efficient manipulation of DNA in Saccharomyces cerevisiae. Genetics 122: 19-27. 
Stavenhagen, J.B. and Zakian, V.A. 1994. Internal tracts of telomeric DNA act as silencers in Saccharomyces cerevisiae. Genes \& Dev. 8: 1411-1422.

Strahl-Bolsinger, S., Hecht, A., Luo, K., and Grunstein, M. 1997. SIR2 and SIR4 interactions differ in core and extended telomeric heterochromatin in yeast. Genes \& Dev. 11: 83-93.

Sung, P., Higgins, D., Prakash, L., and Prakash, S. 1988. Mutation of lysine-48 to arginine in the yeast RAD3 protein abolishes its ATPase and DNA helicase activities but not the ability to bind ATP. EMBO J. 7: 3263-3269.

Tsukamoto, Y., Taggart, A.K.P., and Zakian, V.A. 2001. The role of the Mre11-Rad50-Xrs2 complex in telomerase-mediated lengthening of Saccharomyces cerevisiae telomeres. Curr. Biol. 11: 1328-1335.

Walmsley, R.M., Chan, C.S.M., Tye, B.-K., and Petes, T.D. 1984 Unusual DNA sequences associated with the ends of yeast chromosomes. Nature 310: 157-160.

Wellinger, R.J., Wolf, A.J., and Zakian, V.A. 1993a. Origin activation and formation of single-strand $\mathrm{TG}_{1-3}$ tails occur sequentially in late $\mathrm{S}$ phase on a yeast linear plasmid. Mol. Cell. Biol. 13: 4057-4065.

.1993b. Saccharomyces telomeres acquire single-strand $\mathrm{TG}_{1-3}$ tails late in S phase. Cell 72: 51-60.

Wellinger, R.J., Ethier, K., Labrecque, P., and Zakian, V.A. 1996. Evidence for a new step in telomere maintenance. Cell 85: 423-433.

Wiley, E. and Zakian, V.A. 1995. Extra telomeres, but not internal tracts of telomeric DNA, reduce transcriptional repression at Saccharomyces telomeres. Genetics 139: 67-79.

Wright, J.H. and Zakian, V.A. 1995. Protein-DNA interactions in soluble telosomes from Saccharomyces cerevisiae. Nucleic Acids Res. 23: 1454-1460.

Wright, J.H., Gottschling, D.E., and Zakian, V.A. 1992. Saccharomyces telomeres assume a non-nucleosomal chromatin structure. Genes \& Dev. 6: 197-210.

Zhou, J.-Q., Monson, E.M., Teng, S.-C., Schulz, V.P., and Zakian, V.A. 2000. The Pif1p helicase, a catalytic inhibitor of telomerase lengthening of yeast telomeres. Science 289: 771-774. 


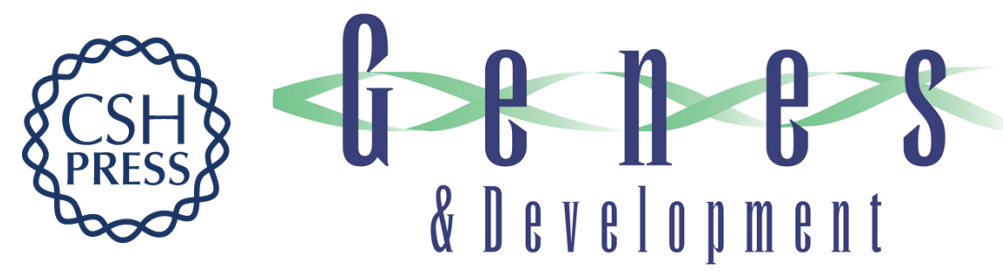

\section{Saccharomyces Rrm3p, a 5' to 3' DNA helicase that promotes replication fork progression through telomeric and subtelomeric DNA}

Andreas S. Ivessa, Jin-Qiu Zhou, Vince P. Schulz, et al.

Genes Dev. 2002, 16:

Access the most recent version at doi:10.1101/gad.982902

References

This article cites 48 articles, 19 of which can be accessed free at: http://genesdev.cshlp.org/content/16/11/1383.full.html\#ref-list-1

License

Email Alerting

Receive free email alerts when new articles cite this article - sign up in the box at the top Service right corner of the article or click here.

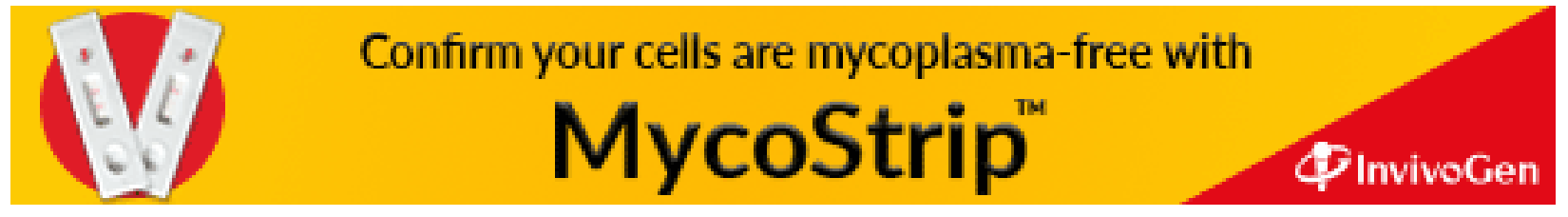

